\title{
Stereochemistry of the insertion of disubstituted alkynes into the metal aminocarbyne bond in diiron complexes.
}

\author{
Vincenzo G. Albano, ${ }^{++}$Luigi Busetto, ${ }^{+}$Fabio Marchetti, ${ }^{+}$Magda Monari, ${ }^{++}$Stefano Zacchini ${ }^{+}$ \\ and Valerio Zanotti ${ }^{+*}$. \\ ${ }^{+}$Dipartimento di Chimica Fisica ed Inorganica, Università di Bologna, Viale Risorgimento 4, \\ I-40136 Bologna, Italy \\ ${ }^{++}$Dipartimento di Chimica “G. Ciamician”, Università di Bologna, Via Selmi 2, I-40126 \\ Bologna, Italy
}

\begin{abstract}
Terminal alkynes $\left(\mathrm{HC} \equiv \mathrm{CR}^{\prime}\right)\left(\mathrm{R}^{\prime}=\mathrm{COOMe}, \mathrm{CH}_{2} \mathrm{OH}\right)$ insert into the metal-carbyne bond of the diiron complexes $\left[\mathrm{Fe}_{2}\{\mu-\mathrm{CN}(\mathrm{Me})(\mathrm{R})\}(\mu-\mathrm{CO})(\mathrm{CO})(\mathrm{NCMe})(\mathrm{Cp})_{2}\right]\left[\mathrm{SO}_{3} \mathrm{CF}_{3}\right](\mathrm{R}=\mathrm{Xyl}$, 1a; $\left.\mathrm{CH}_{2} \mathrm{Ph}, 1 \mathbf{b} ; \mathrm{Me}, \mathbf{1 c} ; \mathrm{Xyl}=2,6-\mathrm{Me}_{2} \mathrm{C}_{6} \mathrm{H}_{3}\right)$, affording the corresponding $\mu$-vinyliminium complexes $\left[\mathrm{Fe}_{2}\left\{\mu-\sigma: \eta^{3}-\mathrm{C}\left(\mathrm{R}^{\prime}\right)=\mathrm{CHC}=\mathrm{N}(\mathrm{Me})(\mathrm{R})\right\}(\mu-\mathrm{CO})(\mathrm{CO})(\mathrm{Cp})_{2}\right]\left[\mathrm{SO}_{3} \mathrm{CF}_{3}\right]\left(\mathrm{R}=\mathrm{Xyl}, \mathrm{R}^{\prime}=\right.$ COOMe, 2; $\mathrm{R}=\mathrm{CH}_{2} \mathrm{Ph}, \mathrm{R}^{\prime}=\mathrm{COOMe}, \mathbf{3} ; \mathrm{R}=\mathrm{Me}, \mathrm{R}^{\prime}=\mathrm{COOMe}, \mathbf{4} ; \mathrm{R}=\mathrm{Xyl}, \mathrm{R}^{\prime}=\mathrm{CH}_{2} \mathrm{OH}, \mathbf{5}$; $\left.\mathrm{R}=\mathrm{Me} \mathrm{R}^{\prime}=\mathrm{CH}_{2} \mathrm{OH}, \mathbf{6}\right)$. The insertion is regiospecific and $\mathrm{C}-\mathrm{C}$ bond formation selectively occurs between the carbyne carbon and the $\mathrm{CH}$ moiety of the alkyne. Disubstituted alkynes $\left(R^{\prime} C \equiv C R^{\prime}\right)$ also insert into the metal-carbyne bond leading to the formation of $\left[\mathrm{Fe}_{2}\left\{\mu-\sigma: \eta^{3}-\right.\right.$ $\left.\left.\mathrm{C}\left(\mathrm{R}^{\prime}\right)=\mathrm{C}\left(\mathrm{R}^{\prime}\right) \mathrm{C}=\mathrm{N}(\mathrm{Me})(\mathrm{R})\right\}(\mu-\mathrm{CO})(\mathrm{CO})(\mathrm{Cp})_{2}\right]\left[\mathrm{SO}_{3} \mathrm{CF}_{3}\right]\left(\mathrm{R}^{\prime}=\mathrm{Me}, \mathrm{R}=\mathrm{Xyl}, \mathbf{8} ; \mathrm{R}^{\prime}=\mathrm{Et}, \mathrm{R}=\mathrm{Xyl}\right.$, 9; $\left.\mathrm{R}^{\prime}=\mathrm{COOMe}, \mathrm{R}=\mathrm{Xyl}, \mathbf{1 0} ; \mathrm{R}^{\prime}=\mathrm{COOMe}, \mathrm{R}=\mathrm{CH}_{2} \mathrm{Ph}, \mathbf{1 1} ; \mathrm{R}^{\prime}=\mathrm{COOMe}, \mathrm{R}=\mathrm{Me}, \mathbf{1 2}\right)$. Complexes $\mathbf{2}, \mathbf{3}, \mathbf{5}, \mathbf{8}, 9$ and $\mathbf{1 1}$, in which the iminium nitrogen is unsymmetrically substituted, give rise to $E$ and/or $Z$ isomers. When iminium substituents are Me and Xyl, the NMR and structural investigations (X-ray structure analysis of $\mathbf{2}$ and $\mathbf{8}$ ) indicate that complexes obtained from terminal alkynes preferentially adopt the $E$ configuration, whereas those derived from internal alkynes are exclusively $Z$. In complexes $\mathbf{8}$ and $\mathbf{9}$, trans and cis isomers have been observed, by NMR spectroscopy, and the structures of trans-8 and cis-8 have been determined by X-ray diffraction studies. Trans to cis isomerization occurs upon heating in THF at reflux temperature. In contrast to the case of $\mathrm{HC} \equiv \mathrm{CR}^{\prime}$, the insertion of 2-hexyne is not regiospecific: $\quad$ both $\quad\left[\mathrm{Fe}_{2}\left\{\mu-\sigma: \eta^{3}-\mathrm{C}\left(\mathrm{CH}_{2} \mathrm{CH}_{2} \mathrm{CH}_{3}\right)=\mathrm{C}(\mathrm{Me}) \mathrm{C}=\mathrm{N}(\mathrm{Me})(\mathrm{R})\right\}(\mu-\right.$
\end{abstract}


$\left.\mathrm{CO})(\mathrm{CO})(\mathrm{Cp})_{2}\right]\left[\mathrm{SO}_{3} \mathrm{CF}_{3}\right] \quad(\mathrm{R}=\mathrm{Xyl}, \quad \mathbf{1 3} ; \mathrm{R}=\mathrm{Me}, \quad 15)$ and $\left[\mathrm{Fe}_{2}\left\{\mu-\sigma: \eta^{3}-\right.\right.$ $\left.\left.\mathrm{C}(\mathrm{Me})=\mathrm{C}\left(\mathrm{CH}_{2} \mathrm{CH}_{2} \mathrm{CH}_{3}\right) \mathrm{C}=\mathrm{N}(\mathrm{Me})(\mathrm{R})\right\}(\mu-\mathrm{CO})(\mathrm{CO})(\mathrm{Cp})_{2}\right]\left[\mathrm{SO}_{3} \mathrm{CF}_{3}\right](\mathrm{R}=\mathrm{Xyl}, \mathbf{1 4}, \mathrm{R}=\mathrm{Me}, \mathbf{1 6})$ are obtained and these compounds are present in solution as a mixture of cis and trans isomers, with predominance of the former.

Keywords: alkyne insertion, carbyne, vinyliminium, diiron complexes, crystal structure

\section{Introduction}

We have recently shown [1] that terminal alkynes ( $\mathrm{HC} \equiv \mathrm{CR}$ ') insert into the metal-carbon bond of diiron $\mu$-aminocarbynes $\left[\mathrm{Fe}_{2}\{\mu-\mathrm{CN}(\mathrm{Me})(\mathrm{R})\}(\mu-\mathrm{CO})(\mathrm{CO})(\mathrm{NCMe})(\mathrm{Cp})_{2}\right]\left[\mathrm{SO}_{3} \mathrm{CF}_{3}\right](\mathrm{R}$ $\left.=\mathrm{Xyl}, \mathbf{1} \mathbf{a} ; \mathrm{CH}_{2} \mathrm{Ph}, \mathbf{1 b} ; \mathrm{Me}, \mathbf{1} \mathbf{c} ; \mathrm{Xyl}=2,6-\mathrm{Me}_{2} \mathrm{C}_{6} \mathrm{H}_{3}\right)$, affording the complexes $\left[\mathrm{Fe}_{2}\left\{\mu-\sigma: \eta^{3}-\right.\right.$ $\left.\left.\mathrm{C}\left(\mathrm{R}^{\prime}\right)=\mathrm{CHC}=\mathrm{N}(\mathrm{Me})(\mathrm{R})\right\}(\mu-\mathrm{CO})(\mathrm{CO})(\mathrm{Cp})_{2}\right]\left[\mathrm{SO}_{3} \mathrm{CF}_{3}\right]\left(\mathrm{R}^{\prime}=\mathrm{SiMe}_{3}, \mathrm{Me}, \mathrm{Bu}^{\mathrm{n}}, \mathrm{p}-\mathrm{Tol}, \mathrm{Ph}, \mathrm{H}\right)$

(Scheme 1), which contain a vinyliminium ligand in a rather unusual bridging coordination mode [2].

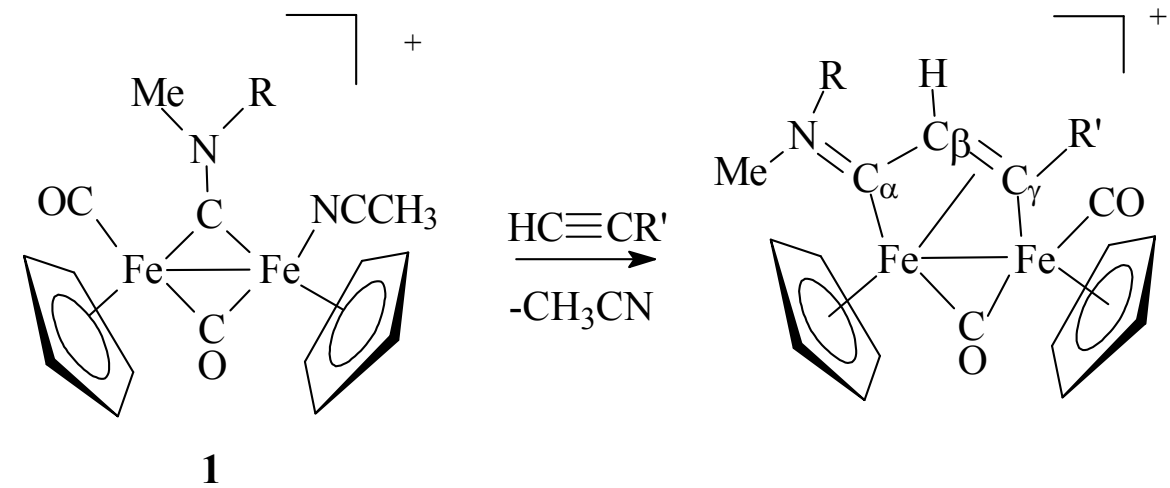

Scheme 1

These reactions, providing $\mathrm{C}-\mathrm{C}$ bond formation at the $\mu$-aminocarbyne carbon [3], represent a remarkable result of our ongoing studies on the reactivity of diiron $\mu$ aminocarbyne complexes containing nitrile ligands [4]. Interestingly, the insertion of primary alkynes is regiospecific: in all of the cases examined, the $\mathrm{C}-\mathrm{C}$ bond was formed between the bridging aminocarbyne and the unsubstituted acetylene carbon, placing the more hindered R' group far from the iminium moiety (Scheme 1). If the substituents at the iminium nitrogen are not identical $(\mathrm{R} \neq \mathrm{Me})$, isomers originate by their different orientation with respect to the $\mathrm{C}=\mathrm{N}$ 
double bond. In particular, when $\mathrm{R}=\mathrm{Xyl}$, the preferred orientation is that with $\mathrm{Xyl}$ cis to $\mathrm{C}_{\beta}$. Insertion of disubstituted acetylenes has also been described, although limited to the symmetrically disubstituted $\mathrm{R}^{\prime} \mathrm{C} \equiv \mathrm{CR}^{\prime}\left(\mathrm{R}^{\prime}=\mathrm{Me}, \mathrm{Et}\right)$ [1]. Herein, we present an extension of our studies to primary alkynes containing functional groups $\left(\mathrm{CO}_{2} \mathrm{Me}, \mathrm{CH}_{2} \mathrm{OH}\right)$, and unsymmetrically disubstituted alkynes. The aim is to establish to what extent the insertion reaction is influenced by the steric hindrance and nature of the acetylene substituents. Finally we want to study in more details the stereo and regiochemistry of the insertion reaction.

\section{Results and discussion}

\subsection{Insertion of monosubstituted alkynes}

The reactions of $\left[\mathrm{Fe}_{2}\{\mu-\mathrm{CN}(\mathrm{Me})(\mathrm{R})\}(\mu-\mathrm{CO})(\mathrm{CO})(\mathrm{NCMe})(\mathrm{Cp})_{2}\right]\left[\mathrm{SO}_{3} \mathrm{CF}_{3}\right] \quad$ (1a-c) with monosubstituted acetylenes $\mathrm{HC} \equiv \mathrm{CR}^{\prime}$ containing a functional group $\left(\mathrm{R}^{\prime}=\mathrm{CO}_{2} \mathrm{Me}, \mathrm{CH}_{2} \mathrm{OH}\right)$, are performed in $\mathrm{CH}_{2} \mathrm{Cl}_{2}$ solution heated at refluxing temperature for $4 \mathrm{~h}$, and result in the formation of the complexes $\left[\mathrm{Fe}_{2}\left\{\mu-\sigma: \eta^{3}-\mathrm{C}\left(\mathrm{R}^{\prime}\right)=\mathrm{CHC}=\mathrm{N}(\mathrm{Me})(\mathrm{R})\right\}(\mu-\mathrm{CO})(\mathrm{CO})(\mathrm{Cp})_{2}\right]\left[\mathrm{SO}_{3} \mathrm{CF}_{3}\right]$ (2-6) (Scheme 2). The presence of functional groups (hydroxy or carboxylate) in the alkyne does not affect its insertion into the metal-carbyne bond, which occurs as previously described [1].

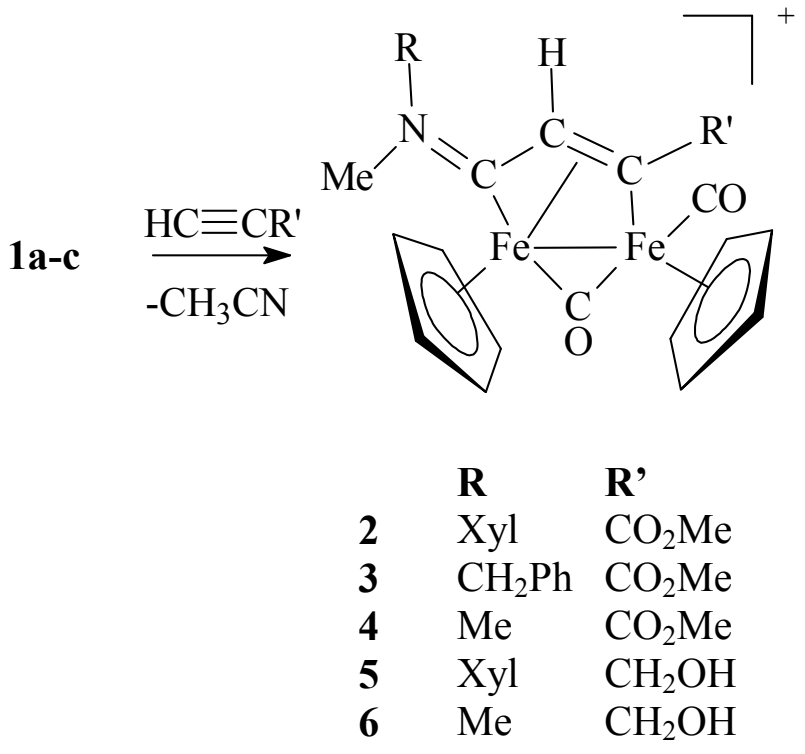

\section{Scheme 2.}


Compounds 2-6 have been obtained in good yields (60-85\%), and characterized by spectroscopy and elemental analyses. Moreover, the complex $\left[\mathrm{Fe}_{2}\left\{\mu-\sigma: \eta^{3}-\right.\right.$ $\left.\left.\mathrm{C}\left(\mathrm{CO}_{2} \mathrm{Me}\right)=\mathrm{CHC}=\mathrm{N}(\mathrm{Me})(\mathrm{Xyl})\right\}(\mu-\mathrm{CO})(\mathrm{CO})(\mathrm{Cp})_{2}\right]\left[\mathrm{SO}_{3} \mathrm{CF}_{3}\right] \quad$ (2) has been structurally characterized by an X-ray diffraction study and the structure of the cation is shown in Figure 1. The stereogeometry is that expected and equivalent both in conformation and bond values to that just reported for $\left[\mathrm{Fe}_{2}\left\{\mu-\sigma: \eta^{3} \mathrm{C}\left(\mathrm{SiMe}_{3}\right)=\mathrm{CHC}=\mathrm{N}(\mathrm{Me})(\mathrm{Xyl})\right\}(\mu-\mathrm{CO})(\mathrm{CO})(\mathrm{Cp})_{2}\right]^{+}[1]$, in which the $-\mathrm{SiMe}_{3}$ group takes the place of $\mathrm{CO}_{2} \mathrm{Me}$. Orientation of the iminium substituents corresponds to the $E$-isomer (Scheme 3), with the Xyl group pointing far from the Cp ligand. Relevant bond parameters are listed in Table 1 and the only comment is that the substituent groups do not have significant effects on the molecular conformation and bond distances.

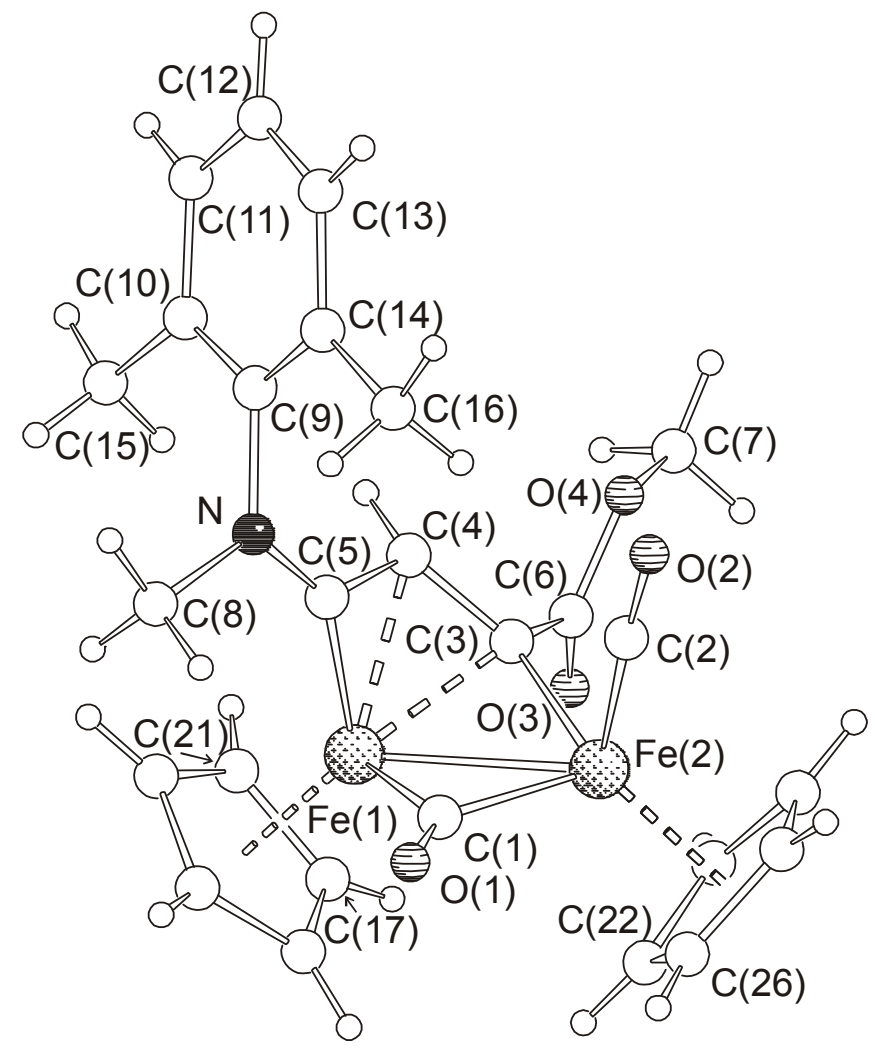

Fig. 1. Molecular structure of the cation of $\left[\mathrm{Fe}_{2}\left\{\mu-\sigma: \eta^{3}-\mathrm{C}\left(\mathrm{CO}_{2} \mathrm{Me}\right)=\mathrm{CHC}=\mathrm{N}(\mathrm{Me})(\mathrm{Xyl})\right\}(\mu-\right.$ $\left.\mathrm{CO})(\mathrm{CO})(\mathrm{Cp})_{2}\right]\left[\mathrm{SO}_{3} \mathrm{CF}_{3}\right](2)$. Only the main image of the disordered $\mathrm{Cp}$ ligand bound to $\mathrm{Fe}(2)$ is drawn. 
The insertion of HCCR' into the Fe-C bond reported in Scheme 2 is regiospecific and the $\mathrm{CR}^{\prime}$ termination $\left(\mathrm{R}^{\prime}=\mathrm{CO}_{2} \mathrm{Me}, \mathrm{CH}_{2} \mathrm{OH}\right)$ is bound exclusively to $\mathrm{Fe}$, presumably to avoid steric interactions with the N-substituents. This is indicated in ${ }^{1} \mathrm{H}$ NMR spectra of 2-6, by the observed resonance in the range 3.9-5.5 ppm, which is attributable to $\mathrm{C}_{\beta} \mathrm{H}$. Furthermore, no signal is detected in the low field range expected for a $\mathrm{C}_{\gamma} \mathrm{H}$ (at about $12 \mathrm{ppm}$ ) which would be generated by the opposite insertion mode $[1,5]$.

The NMR spectra of $\mathbf{2 , 3}$ and $\mathbf{5}$ reveal the presence in solution of two isomers ( $E$ and $Z$ ) generated by different orientations of the $\mathrm{Me}$ and $\mathrm{R}$ substituents in the iminium moiety. Accordingly, complexes 4 and $\mathbf{6}$ having identical N substituents, exhibit one isomer only. In compounds 2 and 5 containing nitrogen substituents (Xyl and $\mathrm{Me}$ ) with different steric hindrance, the $E$-isomer (Scheme 3, and Fig.1) largely prevails. As previously shown [1], the ${ }^{1} \mathrm{H}$ NMR data allow to distinguish between $E$ and $Z$ forms, because the N-Me resonance in the $E$ isomer usually falls in the range 4.1-4.3 ppm, whereas it appears about 0.7 ppm upfield shifted (in the 3.4-3.6 ppm range) in the $Z$ form. Moreover, NOE studies on the major isomer of complex 2 confirm that the methyl group on the nitrogen points far from the $\mathrm{C}_{\beta}-\mathrm{H}$ and close to one $\mathrm{Cp}$ ligand; indeed irradiation of the N-Me resonance (4.05 ppm) resulted in small but significant NOE enhancements of the resonances due to one Cp ligand (5.34 ppm) and the two methyl groups on the Xyl ring (2.29 and $1.73 \mathrm{ppm})$, whereas no effect has been detected on the resonance due to the $\mathrm{C}_{\beta}-\mathrm{H}$.

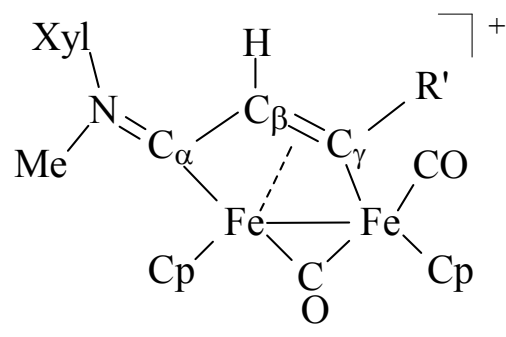

$E$ isomer

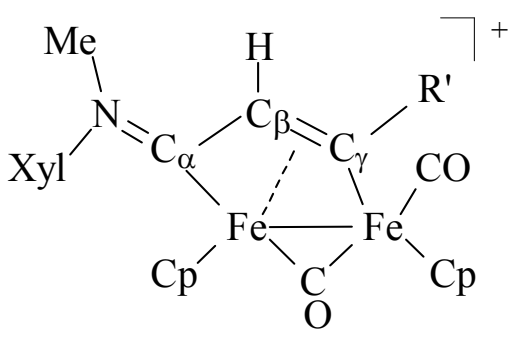

$Z$ isomer

\section{Scheme 3}

The ${ }^{13} \mathrm{C}$ NMR spectra of 2-6 exhibit resonances for the $\mathrm{C}_{\alpha}, \mathrm{C}_{\beta}$ and $\mathrm{C}_{\gamma}$ carbons (e.g. for 4 at 223.1, 51.9 and $183.2 \mathrm{ppm}$, respectively) that are similar to those previously reported for analogous vinyliminium complexes [1]: some slight differences are in line with the electronwithdrawing character of the R' substituent. 
The reactions shown in Scheme 2 indicate a route for introducing functional groups at $\mathrm{C} \gamma$ of the bridging vinyliminium ligand. This would potentially allow the synthesis of a variety of new interesting complexes. For example, compound 5 reacts with $\mathrm{ClSiMe}_{3}$ in the presence of $\mathrm{NEt}_{3}$, yielding the complex $\left[\mathrm{Fe}_{2}\left\{\mu-\sigma: \eta^{3}-\mathrm{C}\left(\mathrm{CH}_{2} \mathrm{OSiMe}_{3}\right)=\mathrm{CHC}=\mathrm{N}(\mathrm{Me})(\mathrm{Xyl})\right\}(\mu-\right.$ $\left.\mathrm{CO})(\mathrm{CO})(\mathrm{Cp})_{2}\right]\left[\mathrm{SO}_{3} \mathrm{CF}_{3}\right](7)$ (Scheme 4). Silylation of the hydroxy group allows purification of 7 by alumina column chromatography, whereas the parent compound $\mathbf{5}$ could only be filtered on celite. This reaction could, in principle, be used to anchor $\mathbf{5}$ on solid silica supports.

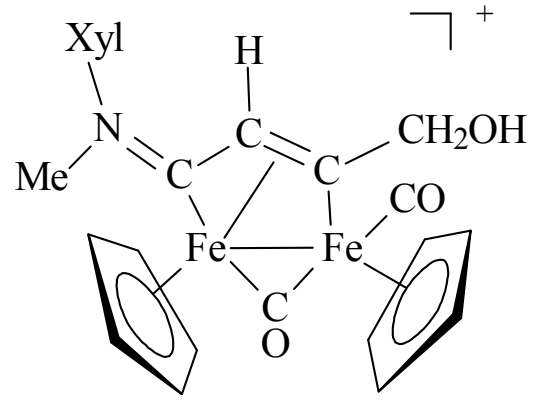

5

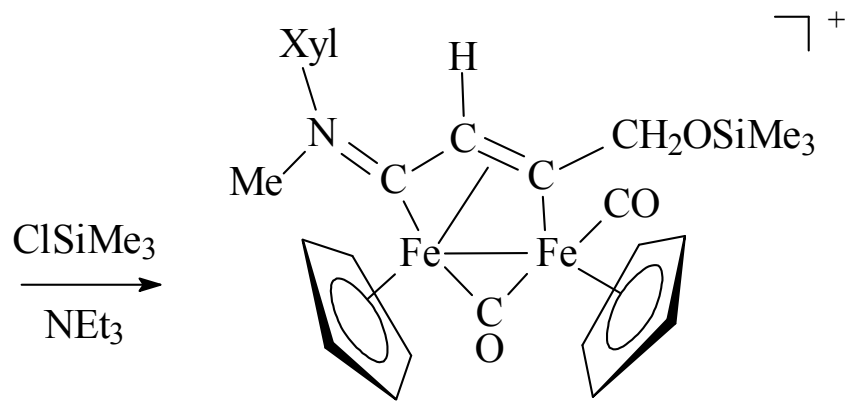

7

\section{Scheme 4}

\subsection{Insertion of symmetrically-disubstituted alkynes}

Disubstituted alkynes (2-butyne and 3-hexyne) also insert into the metal carbyne carbon bond of $1 \mathrm{a}$ to form the corresponding complexes $\left[\mathrm{Fe}_{2}\left\{\mu-\sigma: \eta^{3}-\mathrm{C}\left(\mathrm{R}^{\prime}\right)=\mathrm{C}\left(\mathrm{R}^{\prime}\right) \mathrm{C}=\mathrm{N}(\mathrm{Me})(\mathrm{Xyl})\right\}(\mu-\right.$ $\left.\mathrm{CO})(\mathrm{CO})(\mathrm{Cp})_{2}\right]\left[\mathrm{SO}_{3} \mathrm{CF}_{3}\right]\left(\mathrm{R}^{\prime}=\mathrm{Me}, \mathbf{8} ; \mathrm{Et}, \mathbf{9}\right)$; however, better yields are obtained upon treatment of the chloride complexes $\left[\mathrm{Fe}_{2}\{\mu-\mathrm{CN}(\mathrm{Me})(\mathrm{R})\}(\mu-\mathrm{CO})(\mathrm{CO})(\mathrm{Cl})(\mathrm{Cp})_{2}\right]$ with $\mathrm{AgSO}_{3} \mathrm{CF}_{3}$ in the presence of the appropriate alkyne (Scheme 5). The ${ }^{1} \mathrm{H}$ NMR data of the green compounds 8 and 9 show some significant differences compared to those of the redbrown complexes obtained from primary alkynes (e.g. the N-bonded methyl and one of the $\mathrm{Cp}$ resonances appear up field shifted). In order to establish whether these differences correspond to significant changes in the geometry, the X-ray molecular structure of $\mathbf{8}$ has been determined. The latter is shown in Figure 2 and some important configuration novelties are evident: i) the Cp ligands are mutually trans (trans-8) while they are cis in 2 (Figure 1); ii) the iminium group $-\mathrm{N}(\mathrm{Me})(\mathrm{Xyl})$ is rotated by $180^{\circ}$ with respect to $\mathbf{2}$, producing a $Z$ isomer. 
The ${ }^{1} \mathrm{H}$ NMR data of $\mathbf{8}$ and $\mathbf{9}$ are in good agreement with the geometry observed in the solid state and shown in Figure 2. Resonances due to the N-Me protons in 8 and 9 occur at 3.61 and 3.63 ppm respectively, that is in the range expected for $Z$ isomers.

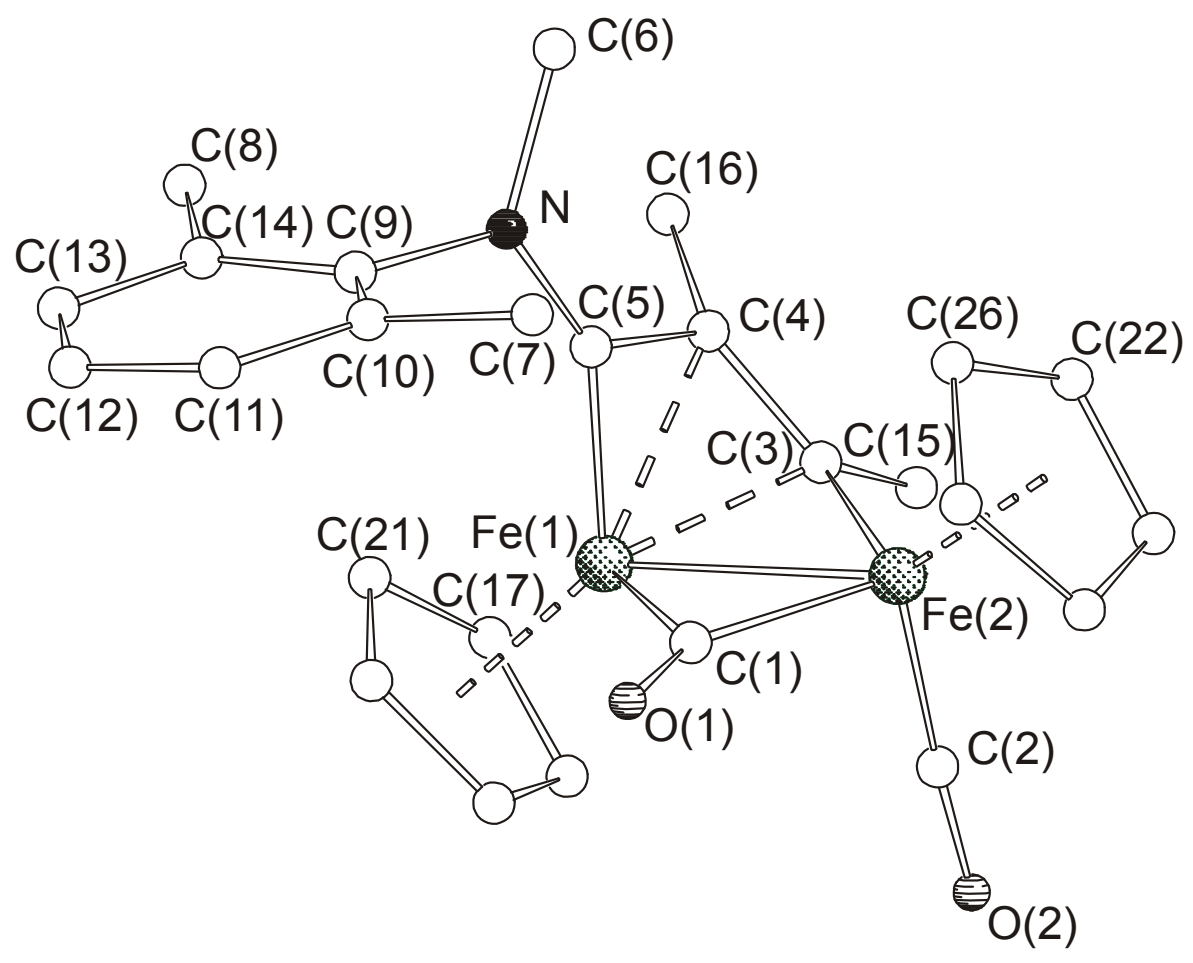

Fig. 2 Molecular structure of the cation of trans-[$\left[\mathrm{Fe}_{2}\left\{\mu-\sigma: \eta^{3}-\right.\right.$ $\left.\mathrm{C}(\mathrm{Me})=\mathrm{C}(\mathrm{Me}) \mathrm{C}=\mathrm{N}(\mathrm{Me})(\mathrm{Xyl})\}(\mu-\mathrm{CO})(\mathrm{CO})(\mathrm{Cp})_{2}\right]\left[\mathrm{SO}_{3} \mathrm{CF}_{3}\right]$ (trans-8). Hydrogen atoms have been omitted for clarity.

Steric factors are likely to be important in favouring $Z$ isomers: increasing steric demand at the $\mathrm{C}_{\beta}$ position, due to a methyl (or ethyl) substituent, presumably forces the Xyl group far apart. The mutual trans - position adopted by the Cp ligands in $\mathbf{8}$ is remarkable because most of the related complexes, containing the $\mathrm{Fe}_{2} \mathrm{Cp}_{2}(\mathrm{CO})_{2}$ frame and bridging carbon ligands display cis-geometry in the solid state, with few exceptions [4c, 6].

In order to investigate its stability, trans-8 has been dissolved in THF and heated at refluxing temperature for $60 \mathrm{~min}$. The treatment has resulted in a complete isomerization to cis-8, as ascertained by an X-ray diffraction study. The structure (Figure 3) also shows that $E$ $Z$ isomerization has not taken place under these conditions. NMR studies evidence that $c i s-\mathbf{8}$ 
retains the Z-configuration also in solution. In particular, the NMe protons resonate at 3.37 ppm, as expected for a Z-isomer. Furthermore, the configuration of complex cis-8 in solution has been confirmed by NOE studies, which reveal strong enhancement of the resonance due to the N-Me when the $\mathrm{C}_{\beta}$-Me is irradiated. Thus, the methyl on the nitrogen points towards the $\mathrm{C}_{\beta}-\mathrm{Me}$, as expected for a $Z$-isomer and, consequently, the $\mathrm{Xyl}$ group points towards one Cp ligand. Accordingly, NOE is shown between the Xyl group and one Cp ligand.

Additionally, a significant NOE has been detected between the two Cp ligands, as expected from the relative cis-geometry. Coherently, analogous investigations carried out on trans $\mathbf{- 8}$ have not evidenced any NOE between the cyclopentadienyl rings.

An analysis of corresponding bond distances in trans-8, cis-8 (Table 2) and $\mathbf{2}$ (Table 1) shows that the observed different geometries ( $E-Z$ and cis-trans) have no effect on all the relevant bond distances.

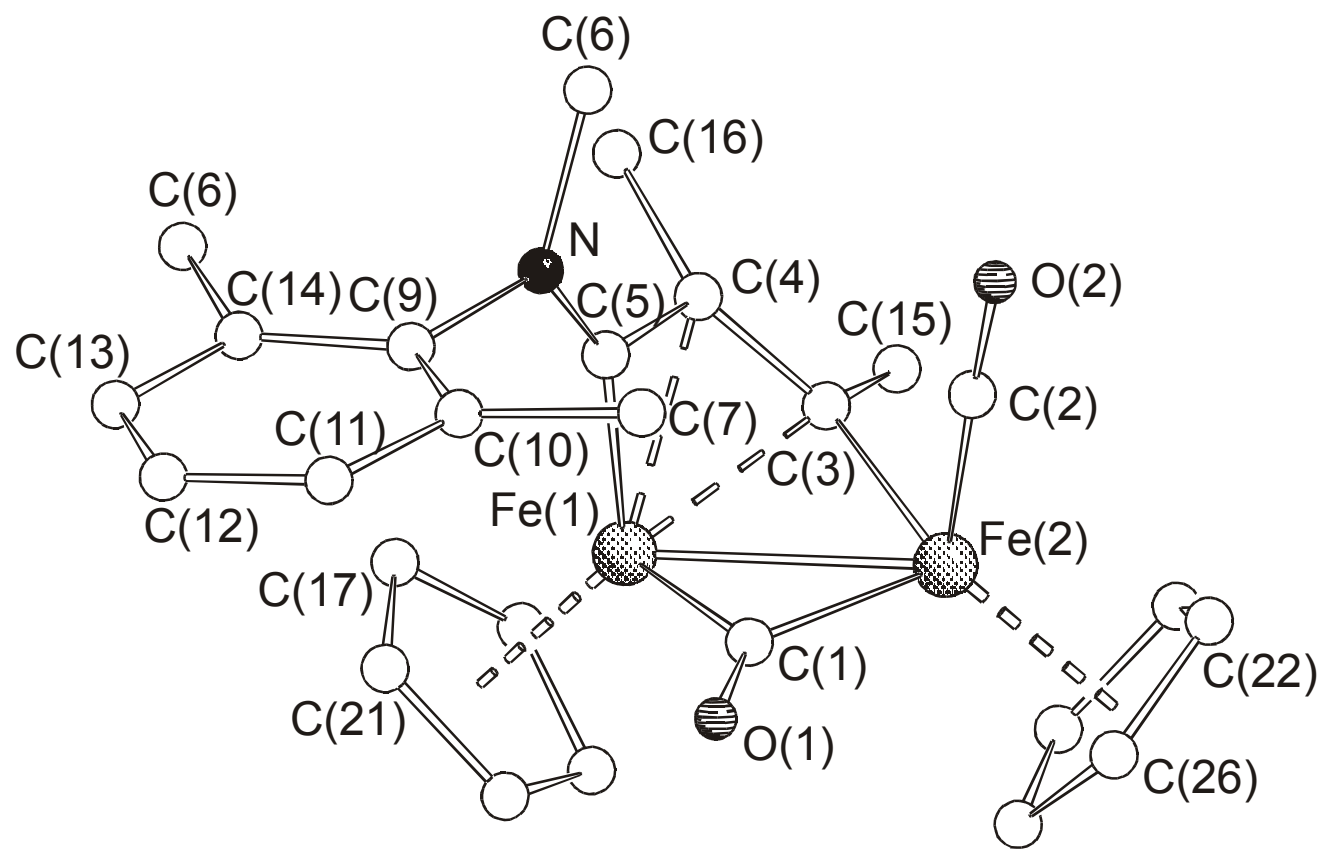

Fig. 3 The molecular structure of the cation of $c i s-\left[\mathrm{Fe}_{2}\left\{\mu-\sigma: \eta^{3}-\right.\right.$ $\left.\mathrm{C}(\mathrm{Me})=\mathrm{C}(\mathrm{Me}) \mathrm{C}=\mathrm{N}(\mathrm{Me})(\mathrm{Xyl})\}(\mu-\mathrm{CO})(\mathrm{CO})(\mathrm{Cp})_{2}\right]\left[\mathrm{SO}_{3} \mathrm{CF}_{3}\right]($ cis-8). Hydrogen atoms have been omitted for clarity. 
The observed isomerization is not surprising, since cis-trans interconversions are rather common in the diiron frame $\mathrm{Fe}_{2}(\mu-\mathrm{CO})(\mathrm{CO})_{2}(\mathrm{Cp})_{2}$. Adams and Cotton put forward a mechanism for the cis-trans isomerization of $\left[\mathrm{Fe}_{2}(\mu-\mathrm{CO})_{2}(\mathrm{CO})_{2}(\mathrm{Cp})_{2}\right]$ which is now a textbook example of the dynamic behaviour of metal carbonyl compounds [7] and cis-trans interconversion has been investigated in other related dinuclear complexes with $\mu$-alkylidenes [8], $\mu$-CNR [9], and $\mu$-vinyl [10].

Analogous behaviour has been observed for $\left[\mathrm{Fe}_{2}\left\{\mu-\sigma: \eta^{3}-\right.\right.$ $\left.\mathrm{C}(\mathrm{Et})=\mathrm{C}(\mathrm{Et}) \mathrm{C}=\mathrm{N}(\mathrm{Me})(\mathrm{Xyl})\}(\mu-\mathrm{CO})(\mathrm{CO})(\mathrm{Cp})_{2}\right]\left[\mathrm{SO}_{3} \mathrm{CF}_{3}\right](\mathbf{9})$. Its synthesis from the chloride complex $\left[\mathrm{Fe}_{2}\{\mu-\mathrm{CN}(\mathrm{Me})(\mathrm{Xyl})\}(\mu-\mathrm{CO})(\mathrm{CO})(\mathrm{Cl})(\mathrm{Cp})_{2}\right]$ affords trans-9, which in turn isomerises to cis-9 upon heating in THF at reflux.

Since the observed trans to cis isomerization is temperature dependent, the formation of vinyliminium complexes from chloride precursors, which can be performed at room temperature, appears to be the most favourable route for obtaining trans isomers. However, it should be noted that the same synthetic method, when applied to primary alkynes, exclusively yields $c i s$-isomers. Therefore the formation of trans-8 and trans-9 is strictly related to the nature of disubstituted alkynes: 2-butyne and 3-hexyne.

The reactions of the acetylene dicarboxylate $\mathrm{MeO}_{2} \mathrm{CC} \equiv \mathrm{CCO}_{2} \mathrm{Me}$ with $\left[\mathrm{Fe}_{2}\{\mu\right.$ $\left.\mathrm{CN}(\mathrm{Me})(\mathrm{R})\}(\mu-\mathrm{CO})(\mathrm{CO})(\mathrm{Cl})(\mathrm{Cp})_{2}\right]\left(\mathrm{R}=\mathrm{Xyl}, \mathrm{CH}_{2} \mathrm{Ph}, \mathrm{Me}\right)$ and $\mathrm{AgSO}_{3} \mathrm{CF}_{3}$ have also been investigated. The insertion reactions occur as expected affording the vinyliminium complexes $\left[\mathrm{Fe}_{2}\left\{\mu-\sigma: \eta^{3}-\mathrm{C}\left(\mathrm{CO}_{2} \mathrm{Me}\right)=\mathrm{C}\left(\mathrm{CO}_{2} \mathrm{Me}\right) \mathrm{C}=\mathrm{N}(\mathrm{Me})(\mathrm{R})\right\}(\mu-\mathrm{CO})(\mathrm{CO})(\mathrm{Cp})_{2}\right]\left[\mathrm{SO}_{3} \mathrm{CF}_{3}\right] \quad(\mathrm{R}=\mathrm{Xyl}, \mathbf{1 0}$; $\mathrm{R}=\mathrm{CH}_{2} \mathrm{Ph}, \mathbf{1 1} ; \mathrm{R}=\mathrm{Me}, \mathbf{1 2}$ ) in good yields (Scheme 5). The ${ }^{1} \mathrm{H}$ NMR spectrum of $\mathbf{1 0}$ indicates the presence of one single isomer. Comparison of the $\mathrm{Cp}$ and NMe resonances (at 5.36, 4.92 and $3.50 \mathrm{ppm}$ respectively) with those of the complexes cis-8 and trans-8 suggests that $\mathbf{1 0}$ adopts cis geometry and $Z$ orientation. The complete absence of trans-10, although the synthesis is performed in the same conditions described for $\mathbf{8}$ and $\mathbf{9}$, should be possibly related to the electron-withdrawing character of the COOMe groups, besides their steric demand. The presence of two carboxylate groups in $\mathbf{1 0}$ is revealed by the IR $v$-CO absorptions at 1733 and $1717 \mathrm{~cm}^{-1}$. Moreover, ${ }^{1} \mathrm{H}$ NMR resonances due to the -COOMe are observed at 4.17 and 3.98 ppm, whereas ${ }^{13} \mathrm{C}$ NMR signals at 176.4 and $166.7 \mathrm{ppm}$ are tentatively attributed to the carboxylate carbons bonded to $\mathrm{C}_{\gamma}$ and $\mathrm{C}_{\beta}$, respectively.

Complex $\left[\mathrm{Fe}_{2}\left\{\mu-\sigma: \eta^{3}-\mathrm{C}(\mathrm{COOMe})=\mathrm{C}(\mathrm{COOMe}) \mathrm{C}=\mathrm{N}(\mathrm{Me})\left(\mathrm{CH}_{2} \mathrm{Ph}\right)\right\}(\mu-\mathrm{CO})(\mathrm{CO})(\mathrm{Cp})_{2}\right]$ $\left[\mathrm{SO}_{3} \mathrm{CF}_{3}\right](\mathbf{1 1})$ exists in solution as a mixture of two isomers, identified, on the basis of their 
NMR data, as $c i s-E$ and $c i s-Z$, with predominance of the latter. Steric arguments should explain the presence of the $E$ isomer, whereas 8, 9 and 10 are exclusively $Z$. In the latter complexes, the steric demanding Xyl group can assume only one of the two possible orientations, corresponding to the $Z$ isomer. By contrast, the lower difference of steric hindrance between $\mathrm{Me}$ and $\mathrm{CH}_{2} \mathrm{Ph}$ in 11, allow the formation of both isomers ( $E$ and $Z$ ) although $Z$ still prevails. Finally, only one cis isomer is observed in the NMR spectra of $\left[\mathrm{Fe}_{2}\left\{\mu-\sigma: \eta^{3}-\mathrm{C}(\mathrm{COOMe})=\mathrm{C}(\mathrm{COOMe}) \mathrm{C}=\mathrm{NMe}_{2}\right\}(\mu-\mathrm{CO})(\mathrm{CO})(\mathrm{Cp})_{2}\right]\left[\mathrm{SO}_{3} \mathrm{CF}_{3}\right] \quad(\mathbf{1 2})$, because the substituents at the iminium nitrogen are identical. The ${ }^{1} \mathrm{H}$ NMR spectrum of $\mathbf{1 2}$ well evidences the different chemical shift of the two N-bonded methyl groups, at 3.81 and 3.22 ppm. These are attributable to the protons pointing toward the $\mathrm{Cp}$ and the $\mathrm{C}_{\beta}(\mathrm{COOMe})$, respectively.

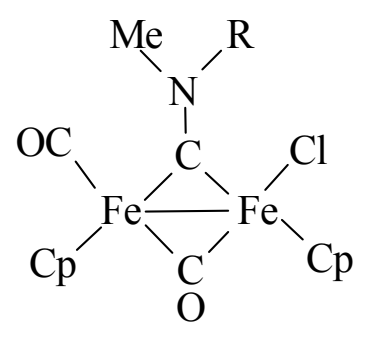

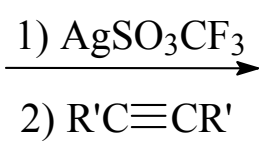

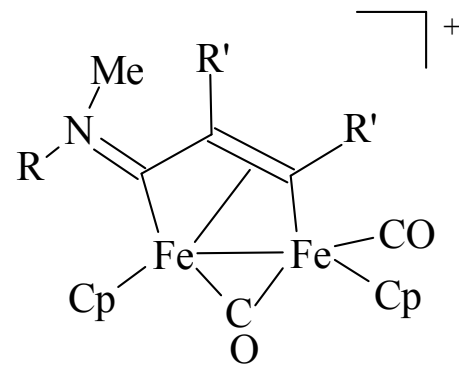

$\begin{array}{lll} & \mathbf{R} & \text { R' } \\ \mathbf{8} & \mathrm{Xyl} & \mathrm{Me} \\ \mathbf{9} & \mathrm{Xyl} & \mathrm{Et} \\ \mathbf{1 0} & \mathrm{Xyl} & \mathrm{CO}_{2} \mathrm{Me} \\ \mathbf{1 1} & \mathrm{CH}_{2} \mathrm{Ph} & \mathrm{CO}_{2} \mathrm{Me} \\ \mathbf{1 2} & \mathrm{Me} & \mathrm{CO}_{2} \mathrm{Me}\end{array}$

\section{Scheme 5.}

\subsection{Insertion of 2-hexyne}

Insertion of an unsymmetrically disubstituted alkyne, like 2-hexyne, into the $\mu$ carbyne-iron bond of 1a, potentially gives rise to eight different isomers, because of the possible E-Z, cis-trans geometries and head-head and head-tail insertion modes. 
As for the other disubstituted alkynes the insertion of 2-hexyne is better performed on the complex $\left[\mathrm{Fe}_{2}\{\mu-\mathrm{CN}(\mathrm{Me})(\mathrm{R})\}(\mu-\mathrm{CO})(\mathrm{CO})(\mathrm{Cl})(\mathrm{Cp})_{2}\right](\mathrm{R}=\mathrm{Xyl}, \mathrm{Me})$, treated in situ with $\mathrm{AgSO}_{3} \mathrm{CF}_{3}$. The reaction of $\left[\mathrm{Fe}_{2}\{\mu-\mathrm{CN}(\mathrm{Me})(\mathrm{Xyl})\}(\mu-\mathrm{CO})(\mathrm{CO})(\mathrm{Cl})(\mathrm{Cp})_{2}\right]$ with 2-hexyne affords a mixture of $\left[\mathrm{Fe}_{2}\left\{\mu-\sigma: \eta^{3}-\mathrm{C}\left(\mathrm{CH}_{2} \mathrm{CH}_{2} \mathrm{CH}_{3}\right)=\mathrm{C}(\mathrm{Me}) \mathrm{C}=\mathrm{N}(\mathrm{Me})(\mathrm{Xyl})\right\}(\mu-\right.$ $\left.\mathrm{CO})(\mathrm{CO})(\mathrm{Cp})_{2}\right]\left[\mathrm{SO}_{3} \mathrm{CF}_{3}\right](\mathbf{1 3})$ and $\left[\mathrm{Fe}_{2}\left\{\mu-\sigma: \eta^{3}-\mathrm{C}(\mathrm{Me})=\mathrm{C}\left(\mathrm{CH}_{2} \mathrm{CH}_{2} \mathrm{CH}_{3}\right) \mathrm{C}=\mathrm{N}(\mathrm{Me})(\mathrm{Xyl})\right\}(\mu-\right.$ $\left.\mathrm{CO})(\mathrm{CO})(\mathrm{Cp})_{2}\right]\left[\mathrm{SO}_{3} \mathrm{CF}_{3}\right](\mathbf{1 4})$, both present as cis and trans isomers (Scheme 6), which could not be separated by chromatography.

The corresponding ${ }^{1} \mathrm{H}$ NMR spectra contain four sets of signals that have been attributed to trans $\mathbf{- 1 3}$, trans $-\mathbf{1 4}$, cis-13 and cis-14 by comparison with the NMR data of cis-8 and trans-8. The relative amounts of the four isomers are 10:4:3:1, respectively. All the isomeric forms show NMe signals at about $3.6 \mathrm{ppm}$, indicating that the methyl group points toward the $\mathrm{C}_{\beta}(Z$ orientation). The predominant isomers (trans-13 and trans-14) are the result of the two possible insertion modes of 2-hexyne into the Fe-carbyne bond: trans-13 shows a methyl group on $\mathrm{C}_{\beta}$ and a $\mathrm{CH}_{2} \mathrm{CH}_{2} \mathrm{CH}_{3}$ group bound to $\mathrm{C}_{\gamma}$; trans $-\mathbf{1 4}$ exhibits the opposite sequence.

Trans-13 and trans-14 can be distinguished, in the ${ }^{1} \mathrm{H}$ NMR spectra, because the resonance of $\mathrm{C}_{\gamma} \mathrm{Me}$ is downfield shifted compared to that of $\mathrm{C}_{\beta} \mathrm{Me}$. The insertion of 2-hexyne into the metal-carbyne bond of $\left[\mathrm{Fe}_{2}\left\{\mu-\mathrm{CN}\left(\mathrm{Me}_{2}\right)\right\}(\mu-\mathrm{CO})(\mathrm{CO})(\mathrm{Cl})(\mathrm{Cp})_{2}\right]$ proceeds similarly, affording a mixture of trans-15, cis-16, and cis-15, in 7:5:2 ratio respectively. Again, the predominant isomer displays trans geometry, with the Me group bonded to the $\mathrm{C}_{\beta}$ carbon. In other words, coupling between the $\mu$-carbyne and the alkyne carbons occurs preferentially with the less hindered alkyne carbon.

Treatment of the reaction mixture containing trans-13, trans-14, cis-13 and cis-14 in THF at refluxing temperature for $4 \mathrm{~h}$ results in complete isomerization of trans $\mathbf{- 1 3}$ and trans14 to $c i s-13$ and cis-14, respectively. The relative amounts of $\mathbf{1 3}$ and $\mathbf{1 4}$ remain unchanged (the ratio is about 13/5) indicating that the cis to trans isomerization is not accompanied by 13-14 interconversion. 
<smiles>[R]N(C)C1C2(Cl)C(=O)C1([Te])C21CCCCC1</smiles>

1) $\mathrm{AgSO}_{3} \mathrm{CF}_{3}$

2) $\mathrm{CH}_{3} \mathrm{C} \equiv \mathrm{CCH}_{2} \mathrm{CH}_{2} \mathrm{CH}_{3}$

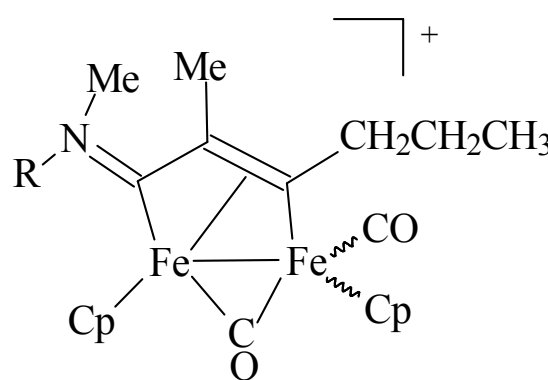

R Xyl

R $\quad \mathrm{Me}$
13

15

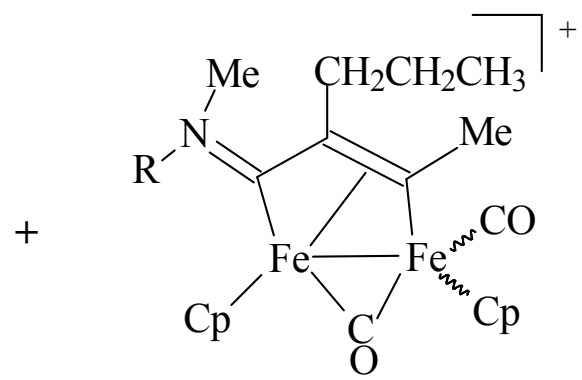

R $\quad$ Xyl $\quad 14$

$\mathrm{R} \quad \mathrm{Me} \quad 16$

\section{Scheme 6}

The formation of $\mathbf{1 3}$ and $\mathbf{1 4}$, as well as $\mathbf{1 5}$ and $\mathbf{1 6}$, shows that the insertion of 2-hexyne is not regiospecific, as that of primary alkynes $\left(\mathrm{HC} \equiv \mathrm{CR}^{\prime}\right)$. The latter is presumably a consequence of the relevant difference in steric demand between $\mathrm{H}$ and $\mathrm{R}$ '.

\section{Conclusions}

Our studies on alkynes insertion into the Fe-carbyne bond have been extended to a number of mono- and di-substituted alkynes with the aim to investigate the nature and geometry of the isomeric species formed. We have found that the stereochemistry of the reaction largely depends on the nature of the alkyne. Insertion of primary alkynes is regiospecific and the products exclusively exhibit cis-geometry. Moreover iminium substituents (Me, Xyl) preferentially adopt one of two possible orientations, corresponding to the $E$ isomer. By contrast, the insertion of disubstituted alkynes (2-butyne, 3-hexyne, 2-hexyne) yields both trans and cis isomers. The latter appear more stable and trans to cis isomerization occurs 
upon thermal treatment. Insertion of disubstituted alkynes, in place of primary alkynes, results in higher steric hindrance on the $C_{\beta}$ position of the vinyl iminium ligand and this has two important consequences: i) the iminium substituents (Me, Xyl) adopt opposite orientation with respect to that found with primary alkynes and corresponding to the $Z$ isomer; ii) the insertion lose its regiospecific character and both insertion modes (head-head or head-tail) are observed.

However, our findings demonstrate that the insertion of alkynes has a general character and tolerates functional groups, which should expand the reactivity of the bridging vinyliminium ligand that we are investigating.

\section{Experimental}

\subsection{General}

Reactions were routinely carried-out under nitrogen using standard Schlenk-line techniques. Solvents were distilled immediately before use under nitrogen from appropriate drying agents. Glassware was oven-dried before use. Infrared spectra were recorded on a Perkin-Elmer 983G spectrophotometer. All NMR measurements were performed on Varian Gemini 300 and Mercury 400 instruments at room temperature. The chemical shifts for ${ }^{1} \mathrm{H}$ and ${ }^{13} \mathrm{C}$ are referenced to internal TMS. Unless otherwise stated, NMR signals due a second isomeric form (where it has been possible to detect and/or resolve them) are italicized. NOE measurements were recorded using DPFGSE-NOE sequence [11]. All the reagents were commercial products (Aldrich) of the highest purity available and used as received. $\left[\mathrm{Fe}_{2}(\mathrm{CO})_{4}(\mathrm{Cp})_{2}\right]$ was purchased from Strem and used as received. Compounds $\left[\mathrm{Fe}_{2}\{\mu-\right.$ $\left.\mathrm{CN}(\mathrm{Me}) \mathrm{R}\}(\mu-\mathrm{CO})(\mathrm{CO})_{2}(\mathrm{Cp})_{2}\right]\left[\mathrm{SO}_{3} \mathrm{CF}_{3}\right]\left(\mathrm{R}=2,6-\mathrm{Me}_{2} \mathrm{C}_{6} \mathrm{H}_{3}, \mathrm{CH}_{2} \mathrm{Ph}, \mathrm{Me}\right)$ [12] and their derivatives $\left[\mathrm{Fe}_{2}\{\mu-\mathrm{CN}(\mathrm{Me}) \mathrm{R}\}(\mu-\mathrm{CO})(\mathrm{CO})(\mathrm{NCMe})(\mathrm{Cp})_{2}\right]\left[\mathrm{SO}_{3} \mathrm{CF}_{3}\right], \quad\left[\mathrm{Fe}_{2}\{\mu-\mathrm{CN}(\mathrm{Me}) \mathrm{R}\}(\mu-\right.$ $\left.\mathrm{CO})(\mathrm{CO})(\mathrm{Cl})(\mathrm{Cp})_{2}\right][4 \mathrm{~b}]$ were prepared as described in the literature.

4.2. Syntheses of $\left[\mathrm{Fe}_{2}\left\{\mu-\sigma: \eta^{3}-\mathrm{C}\left(\mathrm{CO}_{2} \mathrm{Me}\right)=\mathrm{CHC}=\mathrm{N}(\mathrm{Me})(\mathrm{R})\right\}(\mu-\mathrm{CO})(\mathrm{CO})(\mathrm{Cp})_{2}\right]\left[\mathrm{SO}_{3} \mathrm{CF}_{3}\right] \quad(\mathrm{R}$ $\left.=\mathrm{Xyl}, 2 ; \mathrm{R}=\mathrm{CH}_{2} \mathrm{Ph}, 3 ; \mathrm{R}=\mathrm{Me}, 4\right)$. 
Compound 1a (90 mg, $0.15 \mathrm{mmol})$ and $\mathrm{HC} \equiv \mathrm{CCO}_{2} \mathrm{Me}(0.15 \mathrm{~mL}, 1.8 \mathrm{mmol})$, in $\mathrm{CH}_{2} \mathrm{Cl}_{2}$ solution $(10 \mathrm{~mL})$, were heated at refluxing temperature for $4 \mathrm{~h}$. Then, the solvent was removed under reduced pressure; the residue was washed with $\mathrm{Et}_{2} \mathrm{O}(2 \times 10 \mathrm{~mL})$, dissolved in $\mathrm{CH}_{2} \mathrm{Cl}_{2}(10 \mathrm{~mL})$ and filtered through celite. Removal of the solvent in vacuum and a subsequent crystallization at $-20{ }^{\circ} \mathrm{C}$ from $\mathrm{CH}_{2} \mathrm{Cl}_{2}$ solution layered with diethyl ether gave brown crystals of 2. Yield $86 \mathrm{mg}\left(88 \%\right.$ ). Found: C, 48.01; H 3.90. $\mathrm{C}_{27} \mathrm{H}_{26} \mathrm{~F}_{3} \mathrm{Fe}_{2} \mathrm{NO}_{7} \mathrm{~S}$ requires: C, 47.88; H, 3.87\%. IR $\left(\mathrm{CH}_{2} \mathrm{Cl}_{2}\right)$ v(CO) 2013 (vs), 1829 (s), 1712 (m); v(CN) 1635 (m) $\mathrm{cm}^{-1} .{ }^{1} \mathrm{H}$ NMR $\left(\mathrm{CDCl}_{3}\right) \delta$ 7.44-6.92 (m, $\left.3 \mathrm{H}, \mathrm{Me}_{2} \mathrm{C}_{6} H_{3}\right) ; 5.35,5.34,5.24,4.88(\mathrm{~s}, 10 \mathrm{H}$, $\mathrm{Cp}) ; 4.43$ (s, $\left.1 \mathrm{H}, \mathrm{C}_{\beta} \mathrm{H}\right)$; 4.20, 3.57 (s, $\left.3 \mathrm{H}, \mathrm{NMe}\right)$; 4.16, 4.05 (s, $3 \mathrm{H}, \mathrm{CO}_{2} \mathrm{Me}$ ); 2.59, 2.29, 1.93, $1.73\left(\mathrm{~s}, 6 \mathrm{H}, \mathrm{Me}_{2} \mathrm{C}_{6} \mathrm{H}_{3}\right) ;\left(E: Z\right.$ ratio = 6). ${ }^{13} \mathrm{C} \mathrm{NMR}\left(\mathrm{CDCl}_{3}\right) \delta 250.2(\mu-\mathrm{CO}) ; 230.1\left(\mathrm{C}_{\alpha}\right)$; 209.1, $208.2(\mathrm{CO}) ; 186.3\left(\mathrm{C}_{\gamma}\right) ; 177.0\left(\mathrm{CO}_{2} \mathrm{Me}\right), 144.9$ (ipso- $\left.\mathrm{Me}_{2} C_{6} \mathrm{H}_{3}\right) ; 131.5$ - 129.2 $\left(\mathrm{Me}_{2} \mathrm{C}_{6} \mathrm{H}_{3}\right)$; 91.2, 90.9, 89.2, $88.7(\mathrm{Cp}) ; 53.3\left(\mathrm{CO}_{2} \mathrm{Me}\right), 52.2\left(\mathrm{C}_{\beta}\right) ; 46.6(\mathrm{NMe}) ; 18.1$, 17.6, $17.1\left(\mathrm{Me}_{2} \mathrm{C}_{6} \mathrm{H}_{3}\right)$.

Complex $\mathbf{3}$ has been obtained following the same procedure described for the synthesis of 2, by reacting $\left[\mathrm{Fe}_{2}\left\{\mu-\mathrm{CN}(\mathrm{Me})\left(\mathrm{CH}_{2} \mathrm{Ph}\right)\right\}(\mu-\mathrm{CO})(\mathrm{CO})(\mathrm{NCMe})(\mathrm{Cp})_{2}\right]\left[\mathrm{SO}_{3} \mathrm{CF}_{3}\right](\mathbf{1 b} ; 300 \mathrm{mg}$, $0.49 \mathrm{mmol})$ with $\mathrm{HC} \equiv \mathrm{CCO}_{2} \mathrm{Me}(0.15 \mathrm{~mL}, 1.8 \mathrm{mmol})$. Yield $216 \mathrm{mg}(66 \%)$. Found: $\mathrm{C}, 47.08$; H 3.77. $\mathrm{C}_{26} \mathrm{H}_{24} \mathrm{~F}_{3} \mathrm{Fe}_{2} \mathrm{NO}_{7} \mathrm{~S}$ requires: C, 47.09; H, 3.65\%. IR $\left(\mathrm{CH}_{2} \mathrm{Cl}_{2}\right) v(\mathrm{CO}) 2000$ (vs), 1817 (s), $1710(\mathrm{~m}) ; v(\mathrm{CN}) 1671(\mathrm{~m}) \mathrm{cm}^{-1} .{ }^{1} \mathrm{H} \mathrm{NMR}\left(\mathrm{CDCl}_{3}\right) \delta 7.40-7.06\left(\mathrm{~m}, 5 \mathrm{H}, \mathrm{C}_{6} \mathrm{H}_{5}\right) ; 5.58$, 5.40, 5.05, $4.58\left(\mathrm{~d},{ }^{2} \mathrm{~J}_{\mathrm{HH}}=14 \mathrm{~Hz}, \mathrm{CH}_{2} \mathrm{Ph}\right) ; 5.25,5.13\left(\mathrm{~s}, 1 \mathrm{H}, \mathrm{C}_{\beta} \mathrm{H}\right) ; 5.23,5.21,5.19(\mathrm{~s}, 10 \mathrm{H}$, $\mathrm{Cp})$; 4.10, 4.09 (s, $\left.3 \mathrm{H}, \mathrm{CO}_{2} \mathrm{Me}\right) ; 3.68,3.09(\mathrm{~s}, 3 \mathrm{H}, \mathrm{NMe}) ;(\mathrm{E}: \mathrm{Z}$ ratio $=1.2) .{ }^{13} \mathrm{C} \mathrm{NMR}$ $\left(\mathrm{CDCl}_{3}\right) \delta$ 254.5, 252.7 ( $\left.\mu-\mathrm{CO}\right) ; 223.7,223.1\left(\mathrm{C}_{\alpha}\right) ; 208.6,208.4(\mathrm{CO}) ; 184.1,183.9\left(\mathrm{C}_{\gamma}\right)$; $177.3\left(\mathrm{CO}_{2} \mathrm{Me}\right) ; 132.8-129.1\left(\mathrm{C}_{6} \mathrm{H}_{5}\right) ; 90.5,90.4,88.8,88.8(\mathrm{Cp}) ; 68.4,62.0\left(\mathrm{CH}_{2} \mathrm{Ph}\right) ;$ 53.6, $53.1\left(\mathrm{CO}_{2} \mathrm{Me}\right) ; 51.9,51.5\left(\mathrm{C}_{\beta}\right) ; 48.3,42.4(\mathrm{NMe})$.

Complex 4 has been obtained following the same procedure described for the synthesis of 2, by reacting $\left[\mathrm{Fe}_{2}\left\{\mu-\mathrm{CN}(\mathrm{Me})_{2}\right\}(\mu-\mathrm{CO})(\mathrm{CO})(\mathrm{NCMe})(\mathrm{Cp})_{2}\right]\left[\mathrm{SO}_{3} \mathrm{CF}_{3}\right](\mathbf{1 c} ; 85 \mathrm{mg}, 0.16 \mathrm{mmol})$ with $\mathrm{HC} \equiv \mathrm{CCO}_{2} \mathrm{Me}(0.10 \mathrm{~mL}, 1.2 \mathrm{mmol})$. Yield: $72 \mathrm{mg}$ (77 \%). Found: C, 40.84; H 3.43. $\mathrm{C}_{20} \mathrm{H}_{20} \mathrm{~F}_{3} \mathrm{Fe}_{2} \mathrm{NO}_{7} \mathrm{~S}$ requires: C, 40.91; H, 3.43. \%. IR $\left(\mathrm{CH}_{2} \mathrm{Cl}_{2}\right) v(\mathrm{CO}) 2000$ (vs), 1817 (s), $1710(\mathrm{~m}) ; \mathrm{v}(\mathrm{CN}) 1687(\mathrm{~m}) \mathrm{cm}^{-1} .{ }^{1} \mathrm{H}$ NMR $\left(\mathrm{CD}_{2} \mathrm{Cl}_{2}\right) \delta$ 5.15, $5.10(\mathrm{~s}, 10 \mathrm{H}, \mathrm{Cp}) ; 4.94(\mathrm{~s}, 1 \mathrm{H}$, $\left.\mathrm{C}_{\beta} \mathrm{H}\right) ; 4.03$ (s, $\left.3 \mathrm{H}, \mathrm{CO}_{2} \mathrm{Me}\right) ; 3.78,3.23$ (s, $\left.6 \mathrm{H}, \mathrm{NMe}\right) .{ }^{13} \mathrm{C} \mathrm{NMR}\left(\mathrm{CD}_{2} \mathrm{Cl}_{2}\right) 253.1$ ( $\left.\mu-\mathrm{CO}\right)$; $223.1\left(\mathrm{C}_{\alpha}\right) ; 208.6(\mathrm{CO}) ; 183.2\left(\mathrm{C}_{\gamma}\right) ; 177.2\left(\mathrm{CO}_{2} \mathrm{Me}\right) ; 90.3,88.5(\mathrm{Cp}) ; 53.1,45.1(\mathrm{NMe}) ; 51.9$ $\left(\mathrm{C}_{\beta}\right) ; 51.7\left(\mathrm{CO}_{2} \mathrm{Me}\right)$. 
4.3. Syntheses of $\left[\mathrm{Fe}_{2}\left\{\mu-\sigma: \eta^{3}-\mathrm{C}\left(\mathrm{CH}_{2} \mathrm{OH}\right)=\mathrm{CHC}=\mathrm{N}(\mathrm{Me})(\mathrm{R})\right\}(\mu-\mathrm{CO})(\mathrm{CO})(\mathrm{Cp})_{2}\right]\left[\mathrm{SO}_{3} \mathrm{CF}_{3}\right] \quad(\mathrm{R}$ $=X y l, 5 ; R=M e, 6)$.

To a solution of $\mathbf{1 a}(200 \mathrm{mg}, 0.32 \mathrm{mmol})$, in $\mathrm{CH}_{2} \mathrm{Cl}_{2}(15 \mathrm{~mL}), \mathrm{HC} \equiv \mathrm{CCH}_{2} \mathrm{OH}(0.20 \mathrm{~mL}, 3.4$ mmol) was added and the solution was heated at refluxing temperature for $4 \mathrm{~h}$. Then, the solvent was removed under reduced pressure. The residue was washed with $\mathrm{Et}_{2} \mathrm{O}(2 \times 10 \mathrm{~mL})$, dissolved in $\mathrm{CH}_{2} \mathrm{Cl}_{2}(10 \mathrm{~mL})$ and filtered through celite. Removal of the solvent in vacuum afforded 5 as a dark-brown microcrystalline powder. Yield $169 \mathrm{mg}$ (83\%). Found C, 48.17; $\mathrm{H}$ 4.09. $\mathrm{C}_{26} \mathrm{H}_{26} \mathrm{~F}_{3} \mathrm{Fe}_{2} \mathrm{NO}_{6} \mathrm{~S}$ requires: C, 48.10; H, 4.04\%. IR $\left(\mathrm{CH}_{2} \mathrm{Cl}_{2}\right)$ v(CO) 2001 (vs), 1810 (s); v(CN) $1631(\mathrm{~m}) \mathrm{cm}^{-1} .{ }^{1} \mathrm{H} \mathrm{NMR}\left(\mathrm{CDCl}_{3}\right) \delta$ 7.34-6.84 (m, $\left.3 \mathrm{H}, \mathrm{Me}_{2} \mathrm{C}_{6} H_{3}\right) ; 6.31(\mathrm{dd}, 1 \mathrm{H}$, $\left.{ }^{2} \mathrm{~J}_{\mathrm{HH}}=17 \mathrm{~Hz},{ }^{3} \mathrm{~J}_{\mathrm{HH}}=6 \mathrm{~Hz}, \mathrm{CH}_{2} \mathrm{OH}\right) ; 5.65\left(\mathrm{dd}, 1 \mathrm{H},{ }^{2} \mathrm{~J}_{\mathrm{HH}}=17 \mathrm{~Hz},{ }^{3} \mathrm{~J}_{\mathrm{HH}}=5 \mathrm{~Hz}, \mathrm{CH}_{2} \mathrm{OH}\right) ; 5.35$, 5.29, 5.17, $4.74(\mathrm{~s}, 10 \mathrm{H}, \mathrm{Cp}) ; 5.20(\mathrm{~m}, 1 \mathrm{H}, \mathrm{OH}) ; 4.96\left(\mathrm{~s}, 1 \mathrm{H}, \mathrm{C}_{\beta} \mathrm{H}\right) ; 4.14,3.48$ (s, $3 \mathrm{H}$, $\mathrm{NMe}) ; 2.44,2.24,1.97,1.74\left(\mathrm{~s}, 6 \mathrm{H}, M_{2} \mathrm{C}_{6} \mathrm{H}_{3}\right) ;(E: Z$ ratio $=5) .{ }^{13} \mathrm{C} \mathrm{NMR}\left(\mathrm{CDCl}_{3}\right) \delta 254.7$, 253.9 ( $\mu$-CO); 233.4, $230.9\left(\mathrm{C}_{\alpha}\right) ; 213.3,212.4(\mathrm{CO}) ; 210.2,209.5\left(\mathrm{C}_{\gamma}\right)$; 144.6, 140.8 (ipso$\left.\mathrm{Me}_{2} \mathrm{C}_{6} \mathrm{H}_{3}\right) ; 133.6-128.6\left(\mathrm{Me}_{2} C_{6} \mathrm{H}_{3}\right) ; 89.8,87.4,87.1(\mathrm{Cp}) ; 75.2,71.6\left(\mathrm{CH}_{2} \mathrm{OH}\right) ; 51.8\left(\mathrm{C}_{\beta}\right)$; $45.8(\mathrm{NMe}) ; 17.7,17.5,17.0\left(\mathrm{Me}_{2} \mathrm{C}_{6} \mathrm{H}_{3}\right)$.

Complex 6 has been obtained following the same procedure described for the synthesis of 5, by reacting 1c $(120 \mathrm{mg}, 0.23 \mathrm{mmol})$ with $\mathrm{HC} \equiv \mathrm{CCH}_{2} \mathrm{OH}(0.10 \mathrm{~mL}, 1.7 \mathrm{mmol})$; Yield 104 mg (82\%). Found: C, 40.80; H, 3.64. $\mathrm{C}_{19} \mathrm{H}_{20} \mathrm{~F}_{3} \mathrm{Fe}_{2} \mathrm{NO}_{6} \mathrm{~S}$ requires: C, 40.82; H, 3.61\%. IR $\left(\mathrm{CH}_{2} \mathrm{Cl}_{2}\right) v(\mathrm{CO}) 1991(\mathrm{vs}), 1806(\mathrm{~s}) ; \mathrm{v}(\mathrm{CN}) 1681(\mathrm{~m}) \mathrm{cm}^{-1} .{ }^{1} \mathrm{H} \mathrm{NMR}\left(\mathrm{CDCl}_{3}\right) \delta$ 6.16, 5.88 $\left(\mathrm{dd}, 2 \mathrm{H},{ }^{2} \mathrm{~J}_{\mathrm{HH}}=15 \mathrm{~Hz},{ }^{3} \mathrm{~J}_{\mathrm{HH}}=3 \mathrm{~Hz}, \mathrm{CH}_{2} \mathrm{OH}\right) ; 5.25\left(\mathrm{~s}, 1 \mathrm{H}, \mathrm{C}_{\beta} \mathrm{H}\right) ; 5.22,5.02(\mathrm{~s}, 10 \mathrm{H}, \mathrm{Cp})$; $5.00\left(\mathrm{t}, 1 \mathrm{H},{ }^{3} \mathrm{~J}_{\mathrm{HH}}=3 \mathrm{~Hz}, \mathrm{OH}\right) ; 3.80,3.25(\mathrm{~s}, 6 \mathrm{H}, \mathrm{NMe}) .{ }^{13} \mathrm{C} \mathrm{NMR}\left(\mathrm{CDCl}_{3}\right) \delta 257.0(\mu-\mathrm{CO})$; $226.1\left(\mathrm{C}_{\alpha}\right) ; 210.0,209.5\left(\mathrm{CO}\right.$ and $\left.\mathrm{C}_{\gamma}\right) ; 89.0,87.3(\mathrm{Cp}) ; 75.2\left(\mathrm{CH}_{2} \mathrm{OH}\right) ; 50.9,44.8(\mathrm{NMe}) ; 46.5$ $\left(\mathrm{C}_{\beta}\right)$.

4.4. Synthesis of $\left[\mathrm{Fe}_{2}\left\{\mu-\sigma: \eta^{3}-\mathrm{C}\left(\mathrm{CH}_{2} \mathrm{OSiMe}_{3}\right)=\mathrm{CHC}=\mathrm{N}(\mathrm{Me})(\mathrm{Xyl})\right\}(\mu-\right.$ $\left.\mathrm{CO})(\mathrm{CO})(\mathrm{Cp})_{2}\right]\left[\mathrm{SO}_{3} \mathrm{CF}_{3}\right](7)$.

A $\mathrm{CH}_{2} \mathrm{Cl}_{2}$ solution $(10 \mathrm{~mL})$ of complex $6(71 \mathrm{mg}, 0.109 \mathrm{mmol})$ was treated with $\mathrm{Me}_{3} \mathrm{SiCl}$ $(0.5 \mathrm{~mL}, 3.9 \mathrm{mmol})$ and $\mathrm{Et}_{3} \mathrm{~N}(15 \mathrm{mmol})$ at refluxing temperature for $5 \mathrm{~h}$. Solvent removal and chromatography of the residue on alumina column eluting with $\mathrm{CH}_{2} \mathrm{Cl}_{2}$, first, and with $\mathrm{CH}_{3} \mathrm{CN}$, then, gave a yellow-brown fraction. Crystallization from $\mathrm{CH}_{2} \mathrm{Cl}_{2}-\mathrm{Et}_{2} \mathrm{O}$ solution 
afforded 7. Yield $47 \mathrm{mg}\left(60 \%\right.$ ). Found: $\mathrm{C}, 48.19$; $\mathrm{H}$ 4.77. $\mathrm{C}_{29} \mathrm{H}_{34} \mathrm{~F}_{3} \mathrm{Fe}_{2} \mathrm{NO}_{6} \mathrm{SSi}$ requires: $\mathrm{C}$, 48.28; H, 4.75\%. IR $\left(\mathrm{CH}_{2} \mathrm{Cl}_{2}\right)$ v(CO) 1999 (vs), 1817 (s); v(CN) 1632 (m) cm ${ }^{-1} .{ }^{1} \mathrm{H}$ NMR $\left(\mathrm{CDCl}_{3}\right) \delta$ 7.50-6.92(m, $\left.3 \mathrm{H}, \mathrm{Me}_{2} \mathrm{C}_{6} \mathrm{H}_{3}\right) ; 6.05,5.96\left(\mathrm{~d}, 2 \mathrm{H},{ }^{3} \mathrm{~J}_{\mathrm{HH}}=15.6 \mathrm{~Hz}, \mathrm{CH}_{2} \mathrm{OSi}\right) ; 5.39$, $5.10(\mathrm{~s}, 10 \mathrm{H}, \mathrm{Cp}) ; 4.74$ (s, $\left.1 \mathrm{H}, \mathrm{C}_{\beta} \mathrm{H}\right) ; 4.17$ (s, $\left.3 \mathrm{H}, \mathrm{NMe}\right) ; 2.22,1.76$ (s, $\left.6 \mathrm{H}, M_{2} \mathrm{C}_{6} \mathrm{H}_{3}\right) ; 0.21$ $\left(\mathrm{s}, 9 \mathrm{H}, \mathrm{SiMe}_{3}\right) .{ }^{13} \mathrm{C} \mathrm{NMR}\left(\mathrm{CDCl}_{3}\right) \delta 254.0(\mu-\mathrm{CO}) ; 233.2\left(\mathrm{C}_{\alpha}\right) ; 210.2,209.6\left(\mathrm{CO}\right.$ and $\left.\mathrm{C}_{\gamma}\right)$; 144.9-122.7 $\left(\mathrm{Me}_{2} \mathrm{C}_{6} \mathrm{H}_{3}\right)$; 89.9, $87.6(\mathrm{Cp}) ; 75.6\left(\mathrm{CH}_{2} \mathrm{O}\right) ; 51.9(\mathrm{NMe}) ; 49.0\left(\mathrm{C}_{\beta}\right) ; 17.7,17.2$ $\left(\mathrm{Me}_{2} \mathrm{C}_{6} \mathrm{H}_{3}\right) ; 1.01\left(\mathrm{SiMe}_{3}\right)$. ESI-MS: $\mathrm{ES}^{+} 572$.

4.5. Synthesis of trans and cis isomers of $\left[\mathrm{Fe}_{2}\left\{\mu-\sigma: \eta^{3}-C(\mathrm{Me})=C(\mathrm{Me}) C=N(\mathrm{Me})(X y l)\right\}(\mu-\right.$ $\left.\mathrm{CO})(\mathrm{CO})(\mathrm{Cp})_{2}\right]\left[\mathrm{SO}_{3} \mathrm{CF}_{3}\right](\mathbf{8})$.

To a solution of $\left[\mathrm{Fe}_{2}\{\mu-\mathrm{CN}(\mathrm{Me})(\mathrm{Xyl})\}(\mu-\mathrm{CO})(\mathrm{CO})(\mathrm{Cl})(\mathrm{Cp})_{2}\right](232 \mathrm{mg}, 0.48 \mathrm{mmol})$, in $\mathrm{CH}_{2} \mathrm{Cl}_{2}(15 \mathrm{~mL})$, cooled at $-20^{\circ} \mathrm{C}, \mathrm{MeC} \equiv \mathrm{CMe}(0.30 \mathrm{~mL}, 3.8 \mathrm{mmol})$ and $\mathrm{AgSO}_{3} \mathrm{CF}_{3}(174 \mathrm{mg}$, $0.68 \mathrm{mmol}$ ) were added. The mixture was stirred for about 15 minutes. Removal of the solvent and then chromatography on an alumina column, with a mixture of MeCN:THF $(1: 1, \mathrm{v}: \mathrm{v})$ as eluent, gave a green band which was collected. Crystallization from $\mathrm{CH}_{2} \mathrm{Cl}_{2}$ layered with $\mathrm{Et}_{2} \mathrm{O}$ afforded green crystals of trans-8. Yield $188 \mathrm{mg}$ ( 60\%). Found: C, 50.16; $\mathrm{H}, 4.39$. $\mathrm{C}_{27} \mathrm{H}_{28} \mathrm{~F}_{3} \mathrm{Fe}_{2} \mathrm{NO}_{5} \mathrm{~S}$ requires: C, 50.10; H, 4.36\%. IR $\left(\mathrm{CH}_{2} \mathrm{Cl}_{2}\right) v(\mathrm{CO}) 1986$ (vs), 1826 (s); v(CN) $1608(\mathrm{w}) \mathrm{cm}^{-1} .{ }^{1} \mathrm{H}$ NMR $\left(\mathrm{CDCl}_{3}\right) \delta$ 7.48-6.91 (m, $\left.3 \mathrm{H}, \mathrm{Me}_{2} \mathrm{C}_{6} H_{3}\right) ; 4.73,4.47$ (s, 10 $\mathrm{H}, \mathrm{Cp}) ; 3.91$ (s, $\left.3 \mathrm{H}, \mathrm{C}_{\gamma} \mathrm{Me}\right) ; 3.61(\mathrm{~s}, 3 \mathrm{H}, \mathrm{NMe}) ; 2.48,2.08$ (s, $\left.6 \mathrm{H}, M_{2} \mathrm{C}_{6} \mathrm{H}_{3}\right) ; 2.15$ (s, $3 \mathrm{H}$, $\left.\mathrm{C}_{\beta} \mathrm{Me}\right) .{ }^{13} \mathrm{C} \mathrm{NMR}\left(\mathrm{CDCl}_{3}\right) \delta 251.4(\mu-\mathrm{CO}) ; 230.0\left(\mathrm{C}_{\alpha}\right) ; 208.8(\mathrm{CO}) ; 204.4\left(\mathrm{C}_{\gamma}\right) ; 141.8$ (ipso$\left.\mathrm{Me}_{2} C_{6} \mathrm{H}_{3}\right) ; 133.9-128.9\left(\mathrm{Me}_{2} C_{6} \mathrm{H}_{3}\right) ; 89.4,88.4(\mathrm{Cp}) ; 69.4\left(\mathrm{C}_{\beta}\right) ; 49.9(\mathrm{NMe}) ; 37.9(\mathrm{C} \gamma \mathrm{Me})$; 18.1, $17.8\left(\mathrm{Me}_{2} \mathrm{C}_{6} \mathrm{H}_{3}\right) ; 16.5\left(\mathrm{C}_{\beta} \mathrm{Me}\right)$.

A solution of trans $\mathbf{8}(188 \mathrm{mg}, 0.29 \mathrm{mmol})$ in THF $(15 \mathrm{~mL})$ was heated at refluxing temperature for $60 \mathrm{~min}$. Crystallization from $\mathrm{CH}_{2} \mathrm{Cl}_{2}$ solution layered with $\mathrm{Et}_{2} \mathrm{O}$ afforded red crystals of cis-8. Yield $156 \mathrm{mg}$ (83\%). Found: C, 50.13; H, 4.35. $\mathrm{C}_{27} \mathrm{H}_{28} \mathrm{~F}_{3} \mathrm{Fe}_{2} \mathrm{NO}_{5} \mathrm{~S}$ requires: C, 50.10; H, 4.36\%. IR $\left(\mathrm{CH}_{2} \mathrm{Cl}_{2}\right) v(\mathrm{CO}) 1986$ (vs), 1818 (s); v(CN) 1613 (w) cm ${ }^{-1} .{ }^{1} \mathrm{H}$ NMR $\left(\mathrm{CDCl}_{3}\right) \delta$ 7.48-7.00 (m, $\left.3 \mathrm{H}, \mathrm{Me}_{2} \mathrm{C}_{6} \mathrm{H}_{3}\right) ; 5.29,4.68$ (s, $\left.10 \mathrm{H}, \mathrm{Cp}\right) ; 3.88,\left(\mathrm{~s}, 3 \mathrm{H}, \mathrm{C}_{\gamma} \mathrm{Me}\right) ; 3.37$ (s, $3 \mathrm{H}, \mathrm{NMe}) ; 2.49,1.99$ (s, $\left.6 \mathrm{H}, \mathrm{Me}_{2} \mathrm{C}_{6} \mathrm{H}_{3}\right) ; 2.10$ (s, $\left.3 \mathrm{H}, \mathrm{C}_{\beta} \mathrm{Me}\right) .{ }^{13} \mathrm{C} \mathrm{NMR}\left(\mathrm{CDCl}_{3}\right) \delta 254.2$ $(\mu-\mathrm{CO}) ; 230.7\left(\mathrm{C}_{\alpha}\right) ; 210.8(\mathrm{CO}) ; 204.6\left(\mathrm{C}_{\gamma}\right) ; 140.4$ (ipso- $\left.\mathrm{Me}_{2} C_{6} \mathrm{H}_{3}\right) ; 134.1-128.9\left(\mathrm{Me}_{2} C_{6} \mathrm{H}_{3}\right)$; 91.3, 88.1 (Cp); $65.7\left(\mathrm{C}_{\beta}\right) ; 50.1(\mathrm{NMe}) ; 37.7(\mathrm{C} \gamma M e) ; 17.9\left(\mathrm{Me}_{2} \mathrm{C}_{6} \mathrm{H}_{3}\right) ; 16.6\left(\mathrm{C}_{\beta} M e\right)$. 
4.6. Synthesis of trans and cis isomers of $F e_{2}\left\{\mu-\sigma: \eta^{3}-C(E t)=C(E t) C=N(M e)(X y l)\right\}(\mu-$ $\left.\mathrm{CO})(\mathrm{CO})(\mathrm{Cp})_{2}\right]\left[\mathrm{SO}_{3} \mathrm{CF}_{3}\right](\mathbf{9})$

Complex trans-9 was obtained with the same procedure described for trans-8, using $\left[\mathrm{Fe}_{2}\{\mu-\mathrm{CN}(\mathrm{Me})(\mathrm{Xyl})\}(\mu-\mathrm{CO})(\mathrm{CO})(\mathrm{Cl})\left(\mathrm{Cp}_{2}\right)\right] \quad(123 \mathrm{mg}, 0.26 \mathrm{mmol}), \mathrm{CH}_{3} \mathrm{CH}_{2} \mathrm{C} \equiv \mathrm{CCH}_{2} \mathrm{CH}_{3}$ (0.20 mL, $1.8 \mathrm{mmol}$ ), and $\mathrm{AgSO}_{3} \mathrm{CF}_{3}(99 \mathrm{mg}, 0.39 \mathrm{mmol})$. Yield $116 \mathrm{mg}(66 \%)$. Found: $\mathrm{C}$, 51.68; $\mathrm{H}, 4.80 \%$. $\mathrm{C}_{29} \mathrm{H}_{32} \mathrm{~F}_{3} \mathrm{Fe}_{2} \mathrm{NO}_{5} \mathrm{~S}$ requires: $\mathrm{C}, 51.58 ; \mathrm{H}, 4.78 \%$. IR $\left(\mathrm{CH}_{2} \mathrm{Cl}_{2}\right) v(\mathrm{CO}) 1986$ (vs), $1828(\mathrm{~s}) ; \mathrm{v}(\mathrm{CN}) 1605(\mathrm{w}) \mathrm{cm}^{-1} .{ }^{1} \mathrm{H} \mathrm{NMR}\left(\mathrm{CDCl}_{3}\right) \delta$ 7.48-7.23 (m, $\left.3 \mathrm{H}, \mathrm{Me}_{2} \mathrm{C}_{6} H_{3}\right) ; 4.73$, 4.49 (s, $10 \mathrm{H}, \mathrm{Cp}$ ); 4.24, 4.11 (m, $\left.2 \mathrm{H}, \mathrm{C}_{\gamma}-\mathrm{CH}_{2}\right) ; 3.63$ (s, $\left.3 \mathrm{H}, \mathrm{NMe}\right) ; 2.80,1.84$ (m, $2 \mathrm{H}, \mathrm{C}_{\beta^{-}}$ $\left.\mathrm{CH}_{2}\right) ; 2.50,2.13\left(\mathrm{~s}, 6 \mathrm{H}, \mathrm{Me}_{2} \mathrm{C}_{6} \mathrm{H}_{3}\right) ; 1.85\left(\mathrm{t},{ }^{3} \mathrm{~J}_{\mathrm{HH}}=7 \mathrm{~Hz}, 3 \mathrm{H}, \mathrm{C}_{\gamma}-\mathrm{CH}_{2} \mathrm{CH}_{3}\right) ; 1.63\left(\mathrm{t},{ }^{3} \mathrm{~J}_{\mathrm{HH}}=\right.$ $\left.7 \mathrm{~Hz}, 3 \mathrm{H}, \mathrm{C}_{\beta}-\mathrm{CH}_{2} \mathrm{CH}_{3}\right) .{ }^{13} \mathrm{C} \mathrm{NMR}\left(\mathrm{CDCl}_{3}\right) \delta 251.7(\mu-\mathrm{CO}) ; 230.0\left(\mathrm{C}_{\alpha}\right) ; 213.1\left(\mathrm{C}_{\gamma}\right) ; \square 209.2$ (CO); 140.5-129.0 ( $\left.\mathrm{Me}_{2} \mathrm{C}_{6} \mathrm{H}_{3}\right) ; 89.4,89.0(\mathrm{Cp}) ; 67.9\left(\mathrm{C}_{\beta}\right) ; 51.1(\mathrm{NMe}) ; 43.4\left(\mathrm{C}_{\gamma}-\mathrm{CH}_{2}\right) ; 26.0$ $\left(\mathrm{C}_{\beta}-\mathrm{CH}_{2}\right) ; 20.0\left(\mathrm{C}_{\gamma}-\mathrm{CH}_{2} \mathrm{CH}_{3}\right) ; 18.4\left(\mathrm{Me}_{2} \mathrm{C}_{6} \mathrm{H}_{3}\right) ; 14.9\left(\mathrm{C}_{\beta}-\mathrm{CH}_{2} \mathrm{CH}_{3}\right)$.

Cis-9 was obtained as described for cis $\mathbf{- 8}$, by heating a THF solution of trans-9 (116 $\mathrm{mg}, 0.17 \mathrm{mmol}$ ). Yield $65 \mathrm{mg}(56 \%)$. Found: $\mathrm{C}, 51.66 ; \mathrm{H}, 4.79 . \mathrm{C}_{29} \mathrm{H}_{32} \mathrm{~F}_{3} \mathrm{Fe}_{2} \mathrm{NO}_{5} \mathrm{~S}$ requires: C, 51.58; H, 4.78\%. IR ( $\left.\mathrm{CH}_{2} \mathrm{Cl}_{2}\right)$ v(CO) 1984 (vs), 1817 (s); v(CN) 1613 (w) $\mathrm{cm}^{-1} .{ }^{1} \mathrm{H}$ NMR $\left(\mathrm{CDCl}_{3}\right)$ S 7.45-7.23 (m, 3H, $\left.\mathrm{Me}_{2} \mathrm{C}_{6} H_{3}\right) ; 5.30,4.69$ (s, $\left.10 \mathrm{H}, \mathrm{Cp}\right)$; 4.24, 4.11 (m, $\left.2 \mathrm{H}, \mathrm{C}_{\gamma}-\mathrm{CH}_{2}\right)$; 3.40 (s, $3 \mathrm{H}, \mathrm{NMe}$ ); 2.80, $1.84\left(\mathrm{~m}, 2 \mathrm{H}, \mathrm{C}_{\beta}-\mathrm{CH}_{2}\right) ; 2.51,1.97$ (s, $\left.6 \mathrm{H}, \mathrm{Me}_{2} \mathrm{C}_{6} \mathrm{H}_{3}\right) ; 1.80\left(\mathrm{t},{ }^{3} \mathrm{~J}_{\mathrm{HH}}=\right.$ $\left.7 \mathrm{~Hz}, 3 \mathrm{H}, \mathrm{C}_{\gamma}-\mathrm{CH}_{2} \mathrm{CH}_{3}\right) ; 1.54\left(\mathrm{t},{ }^{3} \mathrm{~J}_{\mathrm{HH}}=7 \mathrm{~Hz}, 3 \mathrm{H}, \mathrm{C}_{\beta}-\mathrm{CH}_{2} \mathrm{CH}_{3}\right) .{ }^{13} \mathrm{C} \mathrm{NMR}\left(\mathrm{CDCl}_{3}\right) \delta 253.9(\mu-$ $\mathrm{CO}$ ); $230.6\left(\mathrm{C}_{\alpha}\right) ; 214.0\left(\mathrm{C}_{\gamma}\right) ; 211.0(\mathrm{CO}) ; 140.3$ (ipso- $\left.\mathrm{Me}_{2} \mathrm{C}_{6} \mathrm{H}_{3}\right)$; 134.0, 133.3, 129.8, 129.7, $128.9\left(\mathrm{Me}_{2} \mathrm{C}_{6} \mathrm{H}_{3}\right) ; 90.9,88.0(\mathrm{Cp}) ; 68.1\left(\mathrm{C}_{\beta}\right) ; 51.2(\mathrm{NMe}) ; 42.8\left(\mathrm{C}_{\gamma}-\mathrm{CH}_{2}\right) ; 25.7\left(\mathrm{C}_{\beta}-\mathrm{CH}_{2}\right) ; 20.7$ $\left(\mathrm{C}_{\gamma}-\mathrm{CH}_{2} \mathrm{CH}_{3}\right) ; 18.2\left(\mathrm{Me}_{2} \mathrm{C}_{6} \mathrm{H}_{3}\right) ; 15.5\left(\mathrm{C}_{\beta}-\mathrm{CH}_{2} \mathrm{CH}_{3}\right)$.

4.7. Syntheses of $\left[\mathrm{Fe}_{2}\left\{\mu-\sigma: \eta^{3}-\mathrm{C}\left(\mathrm{CO}_{2} \mathrm{Me}\right)=C\left(\mathrm{CO}_{2} \mathrm{Me}\right) \mathrm{C}=\mathrm{N}(\mathrm{Me})(\mathrm{R})\right\}(\mu\right.$ $\mathrm{CO})(\mathrm{CO})\left(\mathrm{Cp}_{2}\right]\left[\mathrm{SO}_{3} \mathrm{CF}_{3}\right](\mathrm{R}=\mathrm{Xyl}, 10 ; \mathrm{R}=\mathrm{Bz}, 11 ; \mathrm{R}=\mathrm{Me}, 12)$.

A solution of $\left[\mathrm{Fe}_{2}\{\mu-\mathrm{CN}(\mathrm{Me})(\mathrm{Xyl})\}(\mu-\mathrm{CO})(\mathrm{CO})(\mathrm{Cl})(\mathrm{Cp})_{2}\right](38 \mathrm{mg}, 0.079 \mathrm{mmol})$, in $\mathrm{CH}_{2} \mathrm{Cl}_{2}(10 \mathrm{~mL})$, was treated with $\mathrm{CO}_{2} \mathrm{MeC} \equiv \mathrm{CCO}_{2} \mathrm{Me}(0.10 \mathrm{~mL}, 0.81 \mathrm{mmol})$, and then with $\mathrm{AgSO}_{3} \mathrm{CF}_{3}(25 \mathrm{mg}, 0.098 \mathrm{mmol})$. The mixture was stirred for $10 \mathrm{~min}$, and the solvent was removed; the residue was washed with $\mathrm{Et}_{2} \mathrm{O}(2 \times 10 \mathrm{~mL})$, dissolved in $\mathrm{CH}_{2} \mathrm{Cl}_{2}(10 \mathrm{~mL})$ and filtered through celite. Removal of the solvent in vacuum afforded $\mathbf{1 0}$ as orange powder. Yield $51 \mathrm{mg}$ (88 \%). Found: C, 47.32; $\mathrm{H}$ 3.83. $\mathrm{C}_{29} \mathrm{H}_{28} \mathrm{~F}_{3} \mathrm{Fe}_{2} \mathrm{NO}_{9} \mathrm{~S}$ requires: C, 47.37; H, 3.84\%. IR 
$\left(\mathrm{CH}_{2} \mathrm{Cl}_{2}\right) v(\mathrm{CO}) 2007$ (vs), $1843(\mathrm{~s}), 1733(\mathrm{~m}), 1717(\mathrm{~m}) ; \mathrm{v}(\mathrm{CN}) 1629(\mathrm{mw}) \mathrm{cm}^{-1} .{ }^{1} \mathrm{H}$ NMR $\left(\mathrm{CDCl}_{3}\right) \delta$ 7.48-7.20 (m, $\left.3 \mathrm{H}, \mathrm{Me}_{2} \mathrm{C}_{6} \mathrm{H}_{3}\right) ;$ 5.36, 4.92 (s, $\left.10 \mathrm{H}, \mathrm{Cp}\right)$; 4.17, 3.98 (s, $\left.6 \mathrm{H}, \mathrm{CO}_{2} \mathrm{Me}\right)$; 3.50 (s, $3 \mathrm{H}, \mathrm{NMe}) ; 2.56,1.97\left(\mathrm{~s}, 6 \mathrm{H}, \mathrm{Me}_{2} \mathrm{C}_{6} \mathrm{H}_{3}\right) .{ }^{13} \mathrm{C} \mathrm{NMR}\left(\mathrm{CDCl}_{3}\right) \delta 245.6(\mu-\mathrm{CO}) ; 224.2$ $\left(\mathrm{C}_{\alpha}\right) ; 208.5(\mathrm{CO}) ; 190.1\left(\mathrm{C}_{\gamma}\right) ; 176.4\left(\mathrm{C}_{\gamma}-\mathrm{CO}_{2} \mathrm{Me}\right) ; 166.7\left(\mathrm{C}_{\beta}-\mathrm{CO}_{2} \mathrm{Me}\right) ; 140.3$ (ipso- $\left.\mathrm{Me}_{2} \mathrm{C}_{6} \mathrm{H}_{3}\right)$; 133.6, 133.5, 130.2, 129.9, $129.4\left(\mathrm{Me}_{2} \mathrm{C}_{6} \mathrm{H}_{3}\right)$; 92.2, $89.7(\mathrm{Cp}) ; 54.0,53.1\left(\mathrm{CO}_{2} \mathrm{Me}\right)$; 53.0 (NMe); $52.1\left(\mathrm{C}_{\beta}\right) ; 18.1,17.4\left(\mathrm{Me}_{2} \mathrm{C}_{6} \mathrm{H}_{3}\right)$.

Complex 11 has been obtained following the same procedure described for the synthesis of 10, by reacting $\left[\mathrm{Fe}_{2}\left\{\mu-\mathrm{CN}(\mathrm{Me})\left(\mathrm{CH}_{2} \mathrm{Ph}\right)\right\}(\mu-\mathrm{CO})(\mathrm{CO})(\mathrm{Cl})(\mathrm{Cp})_{2}\right](308 \mathrm{mg}, 0.66 \mathrm{mmol})$, in $\mathrm{CH}_{2} \mathrm{Cl}_{2}(15 \mathrm{~mL})$, with $\mathrm{CO}_{2} \mathrm{MeC} \equiv \mathrm{CCO}_{2} \mathrm{Me}(0.30 \mathrm{~mL}, 2.4 \mathrm{mmol})$ and $\mathrm{AgSO}_{3} \mathrm{CF}_{3}(238 \mathrm{mg}$, $0.93 \mathrm{mmol})$. Yield $353 \mathrm{mg}$ (74\%). Found: 46.59; $\mathrm{H}$ 3.58. $\mathrm{C}_{28} \mathrm{H}_{26} \mathrm{~F}_{3} \mathrm{Fe}_{2} \mathrm{NO}_{9} \mathrm{~S}$ requires: $\mathrm{C}$, 46.63; H, 3.63\%. IR $\left(\mathrm{CH}_{2} \mathrm{Cl}_{2}\right) v(\mathrm{CO}) 2008$ (vs), 1829 (s), 1733 (s), 1715 (s); v(CN) 1669 (m) $\mathrm{cm}^{-1} .{ }^{1} \mathrm{H} \mathrm{NMR}\left(\mathrm{CDCl}_{3}\right) \delta 7.51-7.12(\mathrm{~m}, 5 \mathrm{H}, \mathrm{Ph}) ; 5.76,5.43,5.01,4.39\left(\mathrm{~d}, 2 \mathrm{H},{ }^{2} \mathrm{~J}_{\mathrm{HH}}=\right.$ $15 \mathrm{~Hz}, \mathrm{CH}_{2} \mathrm{Ph}$ ); 5.32, 5.28, 5.26, 5.21 (s, $\left.10 \mathrm{H}, \mathrm{Cp}\right) ; 4.14,3.91,3.86$ (s, $6 \mathrm{H}, \mathrm{CO}_{2} \mathrm{Me}$ ); 3.77, $3.05(\mathrm{~s}, 3 \mathrm{H}, \mathrm{NMe}) ;(E: Z$ ratio $=0.5) .{ }^{13} \mathrm{C} \mathrm{NMR}\left(\mathrm{CDCl}_{3}\right) \delta \quad 250.5,249.3(\mu-\mathrm{CO}) ; 220.6$, $219.9\left(\mathrm{C}_{\alpha}\right)$; 207.9, $207.4(\mathrm{CO}) ; 188.9\left(\mathrm{C}_{\gamma}\right) ; 176.2\left(\mathrm{C}_{\gamma}-\mathrm{CO}_{2} \mathrm{Me}\right) ; 166.5\left(\mathrm{C}_{\beta}-\mathrm{CO}_{2} \mathrm{Me}\right)$; 131.6$128.5(\mathrm{Ph}) ;$ 91.6, 91.5, 89.8, 89.6 (Cp); 68.4, $62.1\left(\mathrm{CH}_{2} \mathrm{Ph}\right) ;$ 53.7, 53.6, $52.9\left(\mathrm{CO}_{2} \mathrm{Me}\right) ;$ 51.8, $51.1\left(\mathrm{C}_{\beta}\right) ; 48.5,42.8(\mathrm{NMe})$.

Complex 12 has been obtained following the same procedure described for the synthesis of 10, by reacting $\left[\mathrm{Fe}_{2}\left\{\mu-\mathrm{CN}(\mathrm{Me})_{2}\right\}(\mu-\mathrm{CO})(\mathrm{CO})(\mathrm{Cl})(\mathrm{Cp})_{2}\right](140 \mathrm{mg}, 0.360 \mathrm{mmol})$ in $\mathrm{CH}_{2} \mathrm{Cl}_{2}(15$ $\mathrm{mL})$, with $\mathrm{CO}_{2} \mathrm{MeC} \equiv \mathrm{CCO}_{2} \mathrm{Me}(0.40 \mathrm{~mL}, 3.2 \mathrm{mmol})$ and $\mathrm{AgSO}_{3} \mathrm{CF}_{3}(115 \mathrm{mg}, 0.447 \mathrm{mmol})$. Yield 199 mg (86\%). Found: 40.90; H 3.46. $\mathrm{C}_{22} \mathrm{H}_{22} \mathrm{~F}_{3} \mathrm{Fe}_{2} \mathrm{NO}_{9} \mathrm{~S}$ requires: C, 40.96; H, 3.44\%. IR $\left(\mathrm{CH}_{2} \mathrm{Cl}_{2}\right)$ v(CO) 2007 (vs), 1830 (s), 1733 (s), 1715 (s); v(CN) 1685 (m) cm $\mathrm{cm}^{-1}$. ${ }^{1} \mathrm{H}$ NMR $\left(\mathrm{CD}_{2} \mathrm{Cl}_{2}\right) \delta 5.23,5.12(\mathrm{~s}, 10 \mathrm{H}, \mathrm{Cp}) ; 4.06,3.91\left(\mathrm{~s}, 6 \mathrm{H}, \mathrm{CO}_{2} \mathrm{Me}\right) ; 3.81,3.22(\mathrm{~s}, 6 \mathrm{H}, \mathrm{NMe})$. ${ }^{13} \mathrm{C} \mathrm{NMR}\left(\mathrm{CD}_{2} \mathrm{Cl}_{2}\right) \delta 250.1(\mu-\mathrm{CO}) ; 219.7\left(\mathrm{C}_{\alpha}\right) ; 208.2(\mathrm{CO}) ; 188.9\left(\mathrm{C}_{\gamma}\right) ; 177.1\left(\mathrm{C}_{\gamma}-\mathrm{CO}_{2} \mathrm{Me}\right)$; $166.9\left(\mathrm{C}_{\beta}-\mathrm{CO}_{2} \mathrm{Me}\right) ; 92.3,90.3(\mathrm{Cp}) ; 53.7,52.6\left(\mathrm{CO}_{2} \mathrm{Me}\right) ; 52.1\left(\mathrm{C}_{\beta}\right) ; 54.6,46.9(\mathrm{NMe})$.

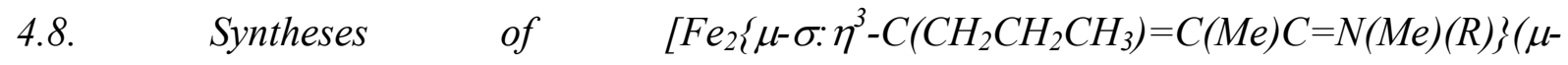
$\left.\mathrm{CO})(\mathrm{CO})(\mathrm{Cp})_{2}\right]\left[\mathrm{SO}_{3} \mathrm{CF}_{3}\right] \quad(\mathrm{R}=\mathrm{Xyl}, \quad 13 ; \mathrm{R}=\mathrm{Me}, \quad 15) \quad$ and $\quad\left[\mathrm{Fe}_{2}\left\{\mu-\sigma: \eta^{3}-\right.\right.$ $\left.\left.\mathrm{C}(\mathrm{Me})=\mathrm{C}\left(\mathrm{CH}_{2} \mathrm{CH}_{2} \mathrm{CH}_{3}\right) \mathrm{C}=\mathrm{N}(\mathrm{Me})(\mathrm{R})\right\}(\mu-\mathrm{CO})(\mathrm{CO})(\mathrm{Cp})_{2}\right]\left[\mathrm{SO}_{3} \mathrm{CF}_{3}\right](\mathrm{R}=\mathrm{Xyl}, \mathbf{1 4} ; \mathrm{R}=\mathrm{Me}, 16)$.

A solution of $\left[\mathrm{Fe}_{2}\{\mu-\mathrm{CN}(\mathrm{Me})(\mathrm{Xyl})\}(\mu-\mathrm{CO})(\mathrm{CO})(\mathrm{Cl})(\mathrm{Cp})_{2}\right](156 \mathrm{mg}, 0.33 \mathrm{mmol})$ and $2-$ hexyne $(0.25 \mathrm{~mL}, 2.2 \mathrm{mmol})$, in $\mathrm{CH}_{2} \mathrm{Cl}_{2}(10 \mathrm{~mL})$, was treated with $\mathrm{AgSO}_{3} \mathrm{CF}_{3}(100 \mathrm{mg}, 0.39$ 
mmol). The mixture was stirred for about 15 minutes. Removal of the solvent and chromatography on an alumina column, using $\mathrm{MeOH}$ as eluent, afforded a green band, corresponding to a mixture of trans-13, trans-14, cis-13, cis-14 (isomer ratio: $10: 4: 3: 1$ ). Yield: $108 \mathrm{mg}$ (49\%). Found: C, 51.63.; $\mathrm{H}$ 4.81. $\mathrm{C}_{29} \mathrm{H}_{32} \mathrm{~F}_{3} \mathrm{Fe}_{2} \mathrm{NO}_{5} \mathrm{~S}$ requires: $\mathrm{C}, 51.58$; $\mathrm{H}$, $4.78 \%$. The solid (100 mg) was dissolved in THF and heated at refluxing temperature for 4 hours. Filtration on a celite pad and removal of the solvent afforded a red solid residue consisting of a mixture of cis-13 and cis-14 (84 mg, 84\%).

trans-13: IR $\left(\mathrm{CH}_{2} \mathrm{Cl}_{2}\right)$ : v(CO) $1986(\mathrm{vs}), 1826(\mathrm{~s}) ; \mathrm{v}(\mathrm{CN}) 1607(\mathrm{~m}) \mathrm{cm}^{-1} .{ }^{1} \mathrm{H} \mathrm{NMR}\left(\mathrm{CDCl}_{3}\right) \delta$ 7.48-7.18 (m, $\left.3 \mathrm{H}, \mathrm{Me}_{2} \mathrm{C}_{6} H_{3}\right)$; 4.77, $4.45(\mathrm{~s}, 10 \mathrm{H}, \mathrm{Cp}) ; 4.09\left(\mathrm{t}, 2 \mathrm{H},{ }^{3} \mathrm{~J}_{\mathrm{HH}}=8 \mathrm{~Hz}, \mathrm{C}_{\gamma}-\mathrm{CH}_{2}\right)$; $3.62(\mathrm{~s}, 3 \mathrm{H}, \mathrm{NMe}) ; 2.47,2.13,2.11\left(\mathrm{~s}, 9 \mathrm{H}, \mathrm{Me}_{2} \mathrm{C}_{6} \mathrm{H}_{3}\right.$ and $\left.\mathrm{C}_{\beta} \mathrm{Me}\right) ; 2.21\left(\mathrm{~m}, 2 \mathrm{H}, \mathrm{C}_{\gamma}-\mathrm{CH}_{2} \mathrm{CH}_{2}\right)$; $1.34\left(\mathrm{t}, 3 \mathrm{H},{ }^{3} \mathrm{~J}_{\mathrm{HH}}=7 \mathrm{~Hz}, \mathrm{C}_{\gamma}-\mathrm{CH}_{2} \mathrm{CH}_{2} \mathrm{CH}_{3}\right) .{ }^{13} \mathrm{C} \mathrm{NMR}\left(\mathrm{CDCl}_{3}\right) \delta 252.2(\mu-\mathrm{CO}) ; 229.8\left(\mathrm{C}_{\alpha}\right)$; 209.2, $209.1\left(\mathrm{C}_{\gamma}\right.$ and CO); 141.9 (ipso- $\left.\mathrm{Me}_{2} C_{6} \mathrm{H}_{3}\right) ; 134.1-128.7\left(\mathrm{Me}_{2} C_{6} \mathrm{H}_{3}\right) ; 88.9,88.7,(\mathrm{Cp})$; $70.6\left(\mathrm{C}_{\beta}\right) ; 54.8\left(\mathrm{C}_{\gamma}-\mathrm{CH}_{2}\right) ; 49.8(\mathrm{NMe}) ; 26.4\left(\mathrm{C}_{\gamma}-\mathrm{CH}_{2} \mathrm{CH}_{2}\right) ; 22.3\left(\mathrm{C}_{\beta}-\mathrm{CH}_{2} \mathrm{CH}_{2}\right) ; 18.1,17.9$ $\left(M_{2} \mathrm{C}_{6} \mathrm{H}_{3}\right) ; 15.9,15.0\left(\mathrm{C}_{\gamma}-\mathrm{CH}_{2} \mathrm{CH}_{2} \mathrm{CH}_{3}\right.$ and $\left.\mathrm{C}_{\beta} \mathrm{Me}\right)$.

trans-14: IR $\left(\mathrm{CH}_{2} \mathrm{Cl}_{2}\right)$ : v(CO) 1986 (vs), $1826(\mathrm{~s}) ; \mathrm{v}(\mathrm{CN}) 1607(\mathrm{~m}) \mathrm{cm}^{-1} .{ }^{1} \mathrm{H} \mathrm{NMR}\left(\mathrm{CDCl}_{3}\right) \delta$ 7.48-7.18 (m, $\left.3 \mathrm{H}, \mathrm{Me}_{2} \mathrm{C}_{6} H_{3}\right) ; 4.65,4.48$ (s, $\left.10 \mathrm{H}, \mathrm{Cp}\right) ; 3.96$ (s, $\left.3 \mathrm{H}, \mathrm{C}_{\gamma} \mathrm{Me}\right) ; 3.58$ (s, $3 \mathrm{H}$, $\mathrm{NMe}) ; 2.70,1.66\left(\mathrm{dt}, 2 \mathrm{H},{ }^{2} \mathrm{~J}_{\mathrm{HH}}=4 \mathrm{~Hz},{ }^{3} \mathrm{~J}_{\mathrm{HH}}=12 \mathrm{~Hz}, \mathrm{C}_{\beta}-\mathrm{CH}_{2}\right) ; 2.49,2.10\left(\mathrm{~s}, 6 \mathrm{H}, \mathrm{Me}_{2} \mathrm{C}_{6} \mathrm{H}_{3}\right)$;

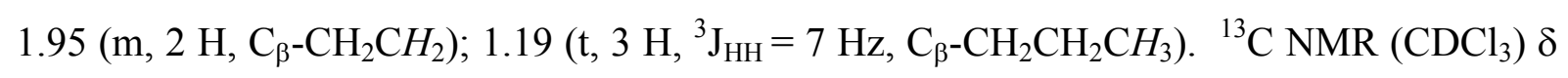
254.1 ( $\mu$-CO); $230.1\left(\mathrm{C}_{\alpha}\right) ; 210.7,210.4\left(\mathrm{C}_{\gamma}\right.$ and $\mathrm{CO}$ ); 140.3 (ipso- $\mathrm{Me}_{2} \mathrm{C}_{6} \mathrm{H}_{3}$ ); 134.1-128.7 $\left(\mathrm{Me}_{2} \mathrm{C}_{6} \mathrm{H}_{3}\right) ; 89.5,88.6(\mathrm{Cp}) ; 71.4\left(\mathrm{C}_{\beta}\right) ; 50.5(\mathrm{NMe}) ; 37.9\left(\mathrm{C}_{\gamma} M e\right) ; 34.2\left(\mathrm{C}_{\beta}-\mathrm{CH}_{2}\right) ; 22.3\left(\mathrm{C}_{\beta}-\right.$ $\left.\mathrm{CH}_{2} \mathrm{CH}_{2}\right) ; 18.6,17.8\left(\mathrm{Me}_{2} \mathrm{C}_{6} \mathrm{H}_{3}\right) ; 14.9\left(\mathrm{C}_{\beta}-\mathrm{CH}_{2} \mathrm{CH}_{2} \mathrm{CH}_{3}\right)$.

cis-13: IR $\left(\mathrm{CH}_{2} \mathrm{Cl}_{2}\right)$ : v(CO) 1986 (vs), $1819(\mathrm{~s}) ; \mathrm{v}(\mathrm{CN}) 1614(\mathrm{~m}) \mathrm{cm}^{-1} .{ }^{1} \mathrm{H}$ NMR $\left(\mathrm{CDCl}_{3}\right) \delta$ 7.48-7.03 (m, $3 \mathrm{H}, \mathrm{Me}_{2} \mathrm{C}_{6} \mathrm{H}_{3}$ ); 5.28, 4.70 (s, $\left.10 \mathrm{H}, \mathrm{Cp}\right) ; 4.13,4.01$ (m, $2 \mathrm{H}, \mathrm{C}_{\gamma}-\mathrm{CH}_{2}$ ); 3.37 (s, $3 \mathrm{H}, \mathrm{NMe}) ; 2.50,1.97\left(\mathrm{~s}, 6 \mathrm{H}, \mathrm{Me}_{2} \mathrm{C}_{6} \mathrm{H}_{3}\right) ; 2.09$ (s, $\left.3 \mathrm{H}, \mathrm{C}_{\beta} \mathrm{Me}\right) ; 1.36\left(\mathrm{t}, 3 \mathrm{H},{ }^{3} \mathrm{~J}_{\mathrm{HH}}=7 \mathrm{~Hz}, \mathrm{C}_{\gamma^{-}}\right.$ $\left.\mathrm{CH}_{2} \mathrm{CH}_{2} \mathrm{CH}_{3}\right) .{ }^{13} \mathrm{C} \mathrm{NMR}\left(\mathrm{CDCl}_{3}\right) \delta 253.8(\mu-\mathrm{CO}) ; 229.9\left(\mathrm{C}_{\alpha}\right) ; 210.6,210.1\left(\mathrm{C}_{\gamma}\right.$ and $\left.\mathrm{CO}\right)$; 140.2 (ipso- $\left.\mathrm{Me}_{2} \mathrm{C}_{6} \mathrm{H}_{3}\right) ; 134.0-128.9\left(\mathrm{Me}_{2} \mathrm{C}_{6} \mathrm{H}_{3}\right) ; 90.9$, $87.9(\mathrm{Cp}) ; 72.0\left(\mathrm{C}_{\beta}\right) ; 52.9\left(\mathrm{C}_{\gamma}-\mathrm{CH}_{2}\right)$; $50.1(\mathrm{NMe}) ; 27.1\left(\mathrm{C}_{\gamma}-\mathrm{CH}_{2} \mathrm{CH}_{2}\right) ; 18.0\left(\mathrm{Me}_{2} \mathrm{C}_{6} \mathrm{H}_{3}\right) ; 15.8,14.7\left(\mathrm{C}_{\gamma}-\mathrm{CH}_{2} \mathrm{CH}_{2} \mathrm{CH}_{3}\right.$ and $\left.\mathrm{C}_{\beta} M e\right)$. cis-14: ${ }^{1} \mathrm{H}$ NMR $\left(\mathrm{CDCl}_{3}\right) \delta$ 7.48-7.03 (m, $\left.3 \mathrm{H}, \mathrm{Me}_{2} \mathrm{C}_{6} \mathrm{H}_{3}\right) ; 5.30,4.68$ (s, $\left.10 \mathrm{H}, \mathrm{Cp}\right) ; 3.95$ (s, 3 $\left.\mathrm{H}, \mathrm{C}_{\gamma} \mathrm{Me}\right) ; 3.37$ (s, $\left.3 \mathrm{H}, \mathrm{NMe}\right) ; 2.49,1.98\left(\mathrm{~s}, 6 \mathrm{H}, M_{2} \mathrm{C}_{6} \mathrm{H}_{3}\right) ; 1.17\left(\mathrm{t}, 3 \mathrm{H},{ }^{3} \mathrm{~J}_{\mathrm{HH}}=7 \mathrm{~Hz}, \mathrm{C}_{\gamma^{-}}\right.$ $\left.\mathrm{CH}_{2} \mathrm{CH}_{2} \mathrm{CH}_{3}\right) .{ }^{13} \mathrm{C} \mathrm{NMR}\left(\mathrm{CDCl}_{3}\right) \delta 210.8,219.9\left(\mathrm{C}_{\gamma}\right.$ and $\left.\mathrm{CO}\right) ; 140.6-128.9\left(\mathrm{Me}_{2} \mathrm{C}_{6} \mathrm{H}_{3}\right) ; 91.2$, 
$88.0(\mathrm{Cp}) ; 50.4(\mathrm{NMe}) ; 37.9\left(\mathrm{C}_{\gamma}-\mathrm{Me}\right) ; 18.7,18.3\left(\mathrm{Me}_{2} \mathrm{C}_{6} \mathrm{H}_{3}\right) ; 34.3,22.9,14.9\left(\mathrm{C}_{\beta}-\right.$ $\mathrm{CH}_{2} \mathrm{CH}_{2} \mathrm{CH}_{3}$ ).

Complexes 15 and 16 have been obtained following the same procedure described for the synthesis of 13 and 14, by reacting $\left[\mathrm{Fe}_{2}\left\{\mu-\mathrm{CN}(\mathrm{Me})_{2}\right\}(\mu-\mathrm{CO})(\mathrm{CO})(\mathrm{Cl})(\mathrm{Cp})_{2}\right](63 \mathrm{mg}, 0.16$ mmol) with $\mathrm{CH}_{3} \mathrm{CH}_{2} \mathrm{CH}_{2} \mathrm{C} \equiv \mathrm{CCH}_{3}(0.20 \mathrm{~mL}, 1.8 \mathrm{mmol})$ and $\mathrm{AgSO}_{3} \mathrm{CF}_{3}(58 \mathrm{mg}, 0.23 \mathrm{mmol})$, in $\mathrm{CH}_{2} \mathrm{Cl}_{2}(10 \mathrm{~mL})$. Isomers ratio: trans-15:cis-16:cis-15 = 7:5:2; yield: $80 \mathrm{mg}, 85 \%$.

Found: $\mathrm{C}, 45.07$; $\mathrm{H}$ 4.45. $\mathrm{C}_{22} \mathrm{H}_{26} \mathrm{~F}_{3} \mathrm{Fe}_{2} \mathrm{NO}_{5} \mathrm{~S}$ requires: $\mathrm{C}, 45.15 ; \mathrm{H}, 4.48 \%$.

IR $\left(\mathrm{CH}_{2} \mathrm{Cl}_{2}\right) v(\mathrm{CO}) 1984$ (vs), 1812 (s); v(CN) $1673(\mathrm{~m}) \mathrm{cm}^{-1}$.

trans-15 : ${ }^{1} \mathrm{H}$ NMR $\left(\mathrm{CDCl}_{3}\right) \delta \quad 4.78,4.51(\mathrm{~s}, 10 \mathrm{H}, \mathrm{Cp}) ; 3.94\left(\mathrm{t}, 2 \mathrm{H},{ }^{3} \mathrm{~J}_{\mathrm{HH}}=9 \mathrm{~Hz}, \mathrm{C}_{\gamma}-\mathrm{CH}_{2}\right)$; 3.85, $3.32(\mathrm{~s}, 6 \mathrm{H}, \mathrm{NMe}) ; 2.03\left(\mathrm{~m}, 2 \mathrm{H}, \mathrm{C}_{\gamma}-\mathrm{CH}_{2} \mathrm{CH}_{2}\right) ; 1.92\left(\mathrm{~s}, 3 \mathrm{H}, \mathrm{C}_{\beta} \mathrm{Me}\right) ; 1.28\left(\mathrm{t}, 3 \mathrm{H},{ }^{3} \mathrm{~J}_{\mathrm{HH}}=\right.$ $\left.7 \mathrm{~Hz}, 3 \mathrm{H}, \mathrm{C}_{\gamma}-\mathrm{CH}_{2} \mathrm{CH}_{2} \mathrm{CH}_{3}\right) .{ }^{13} \mathrm{C} \mathrm{NMR}\left(\mathrm{CDCl}_{3}\right) \delta 255.1$ ( $\left.\mu-\mathrm{CO}\right) ; 225.7\left(\mathrm{C}_{\alpha}\right) ; 210.1(\mathrm{CO})$; $201.9\left(\mathrm{C}_{\gamma}\right)$; 90.4, $87.9(\mathrm{Cp}) ; 68.5\left(\mathrm{C}_{\beta}\right) ; 52.4\left(\mathrm{C}_{\gamma}-\mathrm{CH}_{2}\right) ; 49.5,45.4(\mathrm{NMe}) ; 32.8\left(\mathrm{C}_{\gamma}-\mathrm{CH}_{2} \mathrm{CH}_{2}\right)$; 14.7, $14.6\left(\mathrm{C}_{\gamma}-\mathrm{CH}_{2} \mathrm{CH}_{2} \mathrm{CH}_{3}\right.$ and $\left.\mathrm{C}_{\beta} \mathrm{Me}\right)$.

cis-16: ${ }^{1} \mathrm{H}$ NMR $\left(\mathrm{CDCl}_{3}\right) \quad \delta$ 5.17, $4.89(\mathrm{~s}, 10 \mathrm{H}, \mathrm{Cp}) ; 3.91,3.80,3.14(\mathrm{~s}, 9 \mathrm{H}, \mathrm{NMe}$ and $\mathrm{C} \gamma M e) ; 2.37,1.73\left(\mathrm{dt}, 2 \mathrm{H},{ }^{2} \mathrm{~J}_{\mathrm{HH}}=4 \mathrm{~Hz},{ }^{3} \mathrm{~J}_{\mathrm{HH}}=13 \mathrm{~Hz}, \mathrm{C}_{\beta}-\mathrm{CH}_{2}\right) ; 1.49\left(\mathrm{~m}, 2 \mathrm{H}, \mathrm{C}_{\beta}-\mathrm{CH}_{2} \mathrm{CH}_{2}\right)$; $1.04\left(\mathrm{t}, 3 \mathrm{H},{ }^{3} \mathrm{~J}_{\mathrm{HH}}=7 \mathrm{~Hz}, 3 \mathrm{H}, \mathrm{C}_{\beta}-\mathrm{CH}_{2} \mathrm{CH}_{2} \mathrm{CH}_{3}\right) .{ }^{13} \mathrm{C} \mathrm{NMR}\left(\mathrm{CDCl}_{3}\right) \delta 257.7$ ( $\left.\mu-\mathrm{CO}\right) ; 222.3$ $\left(\mathrm{C}_{\alpha}\right) ; 209.3(\mathrm{CO}) ; 202.5\left(\mathrm{C}_{\gamma}\right) ; 88.9,88.5(\mathrm{Cp}) ; 69.2\left(\mathrm{C}_{\beta}\right) ; 48.2,45.4(\mathrm{NMe}) ; 37.1\left(\mathrm{C}_{\gamma} M e\right) ; 27.0$ $\left(\mathrm{C}_{\beta}-\mathrm{CH}_{2}\right) ; 22.8\left(\mathrm{C}_{\beta}-\mathrm{CH}_{2} \mathrm{CH}_{2}\right) ; 14.6\left(\mathrm{C}_{\beta}-\mathrm{CH}_{2} \mathrm{CH}_{2} \mathrm{CH}_{3}\right)$.

cis-15: ${ }^{1} \mathrm{H}$ NMR $\left(\mathrm{CDCl}_{3}\right) \delta$ 5.18, 4.95 (s, $\left.10 \mathrm{H}, \mathrm{Cp}\right) ; 3.86,3.15$ (s, $\left.6 \mathrm{H}, \mathrm{NMe}\right) ; 1.89(\mathrm{~s}, 3 \mathrm{H}$, $\left.\mathrm{C}_{\beta} \mathrm{Me}\right)$.

\subsection{Crystallography}

The X-ray intensity data for $\mathbf{2}, c i s-\mathbf{8}$ and trans $\mathbf{8}$ were measured on a Bruker AXS SMART 2000 diffractometer, equipped with a CCD detector. For all crystals, a full sphere of reciprocal space was scanned by $0.3^{\circ} \omega$ steps, with the detector kept at $5.0 \mathrm{~cm}$ from the sample. Intensity control was monitored by recollecting the initial 50 frames at the end of the data collection and analyzing the duplicate reflections. The software SMART [13] was used for collecting frames of data, indexing reflections and determination of lattice parameters. The collected frames were then processed for integration by the SAINT program [13] and an empirical absorption correction was applied using SADABS [14]. The structures were solved by direct methods (SIR 97) [15] and subsequent Fourier syntheses and refined by full-matrix 
least-squares on $\mathrm{F}^{2}$ (SHELXTL) [16], using anisotropic thermal parameters for all nonhydrogen atoms. In 2, one cyclopentadienyl ring [bound to $\mathrm{Fe}(2)$ ] was found disordered over two positions and the site occupation factors were refined yielding the values 0.65 and 0.35 , respectively. Some disorder was also detected in the $\mathrm{CF}_{3} \mathrm{SO}_{3}{ }^{-}$anion of cis-8 for the fluorine and oxygen atoms which were refined over two sites yielding occupation factors of 0.70 and 0.50 for the main images of the $\mathrm{O}$ and $\mathrm{F}$ atoms, respectively. All hydrogen atoms, except the hydrogen bound to the $\mathrm{C}_{\beta}$ carbon $[\mathrm{C}(4)]$ in complex 2 which was located in the Fourier map and refined isotropically, were added in calculated positions, included in the final stage of refinement with isotropic thermal parameters, $U(\mathrm{H})=1.2 U_{\text {eq }}(\mathrm{C})\left[U(\mathrm{H})=1.5 U_{\text {eq }}(\mathrm{C}-\mathrm{Me})\right]$, and allowed to ride on their carrier carbons. Crystal data and details of the data collection for all structures are reported in Table 3. SCHAKAL97 has been used for the graphical representations [17].

\section{. Supplementary material}

Crystallographic data for the structural analyses have been deposited with the Cambridge Crystallographic Data Centre, CCDC no. 216794 for 2, no. 216795 for trans-8 and 216796 for cis-8. Copies of this information can be obtained free of charge from the Director, CCDC, 12 Union Road, Cambridge CB2 1EZ, UK (fax: +44-1233-336033; e-mail: deposit@ccdc.cam.ac.uk or http://www.ccdc.cam.ac.uk).

\section{Acknowledgment}

We thank the Ministero dell'Universita' e della Ricerca Scientifica e Tecnologica (M.I.U.R.) (project: 'New strategies for the control of reactions: interactions of molecular fragments with metallic sites in unconventional species') and the University of Bologna for financial support. 


\section{References}

[1] V.G. Albano, L. Busetto, F. Marchetti, M. Monari, S. Zacchini, V. Zanotti, Organometallics 22 (2003) 1326.

[2] examples of vinyliminium complexes in different coordination modes include: (a) D.J. Bernard, M.A. Esteruelas, A.M. Lopez, J. Modrego, M.C. Puerta, P. Valerga, Organometallics 18 (1999) 4995; (b) N. Mantovani, L. Marvelli, R. Rossi, V. Bertolasi, C. Bianchini, I. de los Rios, M. Peruzzini, Organometallics 21 (2002) 2382; (c) A.S. Gamble, P.S. White, J.L. Templeton, Organometallics, 10 (1991) 693; (d) C.J. Adams, K.M. Anderson, I.M. Bartlett, N.G. Connelly, A.G. Orpen, T.J. Paget, H. Phetmung, D.W. Smith, J. Chem. Soc., Dalton Trans. (2001) 1284; (e) M.R. Churchill,. C.H. Lake, R.A. Lashewycz-Rubycz, H. Yao, R.D. McCargar, J.B. Keister, J. Organomet. Chem. 452 (1993) 151; (f) S. Aime, D. Osella, A.J. Deeming, A.J. Arce, J. Chem. Soc. Dalton Trans. (1986) 1459.

[3] (a) V. G. Albano, L. Busetto, C. Camiletti, C. Castellari, M. Monari, V. Zanotti, J. Chem. Soc. Dalton Trans. (1997) 4671; (b) V.G. Albano, S. Bordoni, L. Busetto, C. Camiletti, M. Monari, A. Palazzi, F. Prestopino, V. Zanotti, J. Chem. Soc., Dalton Trans. (1997) 4665.

[4] (a) V.G Albano,. L. Busetto, F. Marchetti, M. Monari, V. Zanotti, J. Organomet Chem. 649 (2002) 64; (b) V.G. Albano, L. Busetto, M. Monari, V. Zanotti, J. Organomet. Chem. 606 (2000) 163; (c) V.G. Albano, S. Bordoni, L. Busetto, F. Marchetti, M. Monari, V. Zanotti, J.Organomet. Chem. in the press.

[5] (a) A.F. Dyke, S.A.R. Knox, P.J. Naish, G.E. Taylor, J. Chem. Soc., Chem.Commun. (1980) 409; (b) D.L. Davies, A.F. Dyke, S.A.R. Knox, M.J. Morris, J. Organomet. Chem. 215 (1981) C30; (c) A.F. Dyke, S.A.R. Knox,. P.J. Naish, G.E. Taylor, J. Chem. Soc., Dalton Trans. (1982) 1297; (d) B.P. Gracey, S.A.R.; Knox, K.A. Macpherson, A.G. Orpen, S.R. Stobart, J. Chem. Soc., Dalton Trans. (1985) 1935.

[6] (a) V. Zanotti, S. Bordoni, L. Busetto, L. Carlucci, A. Palazzi, R. Serra, V.G. Albano, M. Monari, F. Prestopino, F. Laschi, P. Zanello, Organometallics 14 (1995) 5232; (b) R.F Bryan, P.T. Green, J.Chem. Soc. A, (1970) 3064.

[7] (a) F.A. Cotton, G. Wilkinson in Advanced inorganic Chemistry $5^{\text {th }}$ ed. Wiley New York 1988 pp 1325-1327; (b) R.D. Adams, F.A. Cotton, J. Am. Chem. Soc. 95 (1973) 6589. 
[8] (a) C.P. Casey, K.P. Gable, D.M. Roddick, Organometallics 9 (1990) 221; (b) N.C. Schroeder, R. Funchess, R.A. Jacobson, R.J. Angelici, Organometallics 8 (1989) 521; (c) R.E. Colborn, D.L. Davies A.F. Dyke, S.A.R. Knox, K.A. Mead, A.G. Orpen, J. Chem. Soc., Dalton Trans. (1989) 1799; (d) R.E. Colborn, A.F. Dyke, S.A.R. Knox, K.A. Mead, P Woodward, J. Chem. Soc., Dalton Trans. (1983) 2099.

[9] N.A. Guillevic, E.L. Hancox, B.E. Mann, J. Chem. Soc., Dalton Trans. 1992, 1729.

[10] A.F. Dyke, S.A.R. Knox, M. Morris, P.J. Naish, J. Chem. Soc., Dalton Trans. 1983, 1417.

[11] K. Stott, J. Stonehouse, J. Keeler, T.L. Hwang, A.J. Shaka, J. Am. Chem. Soc. 117 (1995) 4199.

[12] (a) G. Cox, C. Dowling, A.R. Manning, P. McArdle, D. Cunningham, J. Organomet. Chem. 438 (1992) 143; (b) K. Boss, C. Dowling, A.R. Manning, J. Organomet. Chem. 509 (1996) 19.

[13] SMART \& SAINT Software Reference Manuals, version 5.051 (Windows NT Version), Bruker Analytical X-ray Instruments Inc.: Madison, Wi, 1998.

[14] G. M. Sheldrick, SADABS, program for empirical absorption correction, University of Göttingen, Germany, 1996.

[15] A. Altomare, G. Cascarano, C. Giacovazzo, A. Guagliardi, A.G.G. Moliterni, M.C. Burla, G. Polidori, M. Camalli, D. Siliqi, Acta. Crystallogr., Sect. A 52 (1996) C79.

[16] G.M. Sheldrick, SHELXTLplus (Windows NT Version) Structure Determination Package; Version 5.1. Bruker Analytical X-ray Instruments Inc.: Madison, WI, USA, 1998.

[17] E. Keller, SCHAKAL97, Graphical Representation of Molecular Models, University of Freiburg, Germany, 1997. 
Table 1. Selected bond lengths $(\AA)$ and angles $\left({ }^{\circ}\right)$ for 2.

$\begin{array}{llll}\mathrm{Fe}(1)-\mathrm{Fe}(2) & 2.549(1) & \mathrm{C}(8)-\mathrm{N} & 1.465(8) \\ \mathrm{Fe}(1)-\mathrm{C}(3) & 2.017(6) & \mathrm{C}(9)-\mathrm{N} & 1.467(1) \\ \mathrm{Fe}(1)-\mathrm{C}(4) & 2.081(6) & \mathrm{C}(3)-\mathrm{C} 6) & 1.492(9) \\ \mathrm{Fe}(1)-\mathrm{C}(5) & 1.843(6) & \mathrm{C}(6)-\mathrm{O}(4) & 1.325(8) \\ \mathrm{Fe}(1)-\mathrm{C}(1) & 1.954(7) & \mathrm{C}(6)-\mathrm{O}(3) & 1.177(8) \\ \mathrm{Fe}(2)-\mathrm{C}(1) & 1.929(7) & \mathrm{O}(4)-\mathrm{C}(7) & 1.454(9) \\ \mathrm{C}(1)-\mathrm{O}(1) & 1.155(8) & \mathrm{Fe}(2)-\mathrm{C}(2) & 1.750(9) \\ \mathrm{Fe}(2)-\mathrm{C}(3) & 1.954(6) & \mathrm{C}(2)-\mathrm{O}(2) & 1.137(9) \\ \mathrm{C}(3)-\mathrm{C}(4) & 1.396(8) & \mathrm{Fe}(1)-\mathrm{C}(\mathrm{Cp})(\mathrm{av}) & 2.096 \\ \mathrm{C}(4)-\mathrm{C}(5) & 1.421(8) & \mathrm{Fe}(2)-\mathrm{C}(\mathrm{Cp})(\mathrm{av})^{\mathrm{a}} & 2.126 \\ \mathrm{C}(5)-\mathrm{N} & 1.289(7) & & \\ & & & \\ \mathrm{C}(9)-\mathrm{N}-\mathrm{C}(5) & 121.7(5) & \mathrm{Fe}(1)-\mathrm{C}(5)-\mathrm{C}(4) & 78.0(3) \\ \mathrm{C}(5)-\mathrm{C}(4)-\mathrm{C}(3) & 116.3(5) & \mathrm{C}(5)-\mathrm{N}-\mathrm{C}(8) & 121.8(5) \\ \mathrm{N}-\mathrm{C}(5)-\mathrm{C}(4) & 133.5(5) & \mathrm{C}(8)-\mathrm{N}-\mathrm{C}(9) & 116.4(4) \\ \mathrm{Fe}(2)-\mathrm{C}(3)-\mathrm{C}(4) & 125.3(4) & & \\ & & \end{array}$


Table 2 Selected bond lengths $(\AA)$ and angles $\left(^{\circ}\right)$ for cis-8 and trans-8.

$\begin{array}{lll} & \text { trans-8 } & \text { cis-8 } \\ \mathrm{Fe}(1)-\mathrm{Fe}(2) & 2.559(1) & 2.562(1) \\ \mathrm{Fe}(1)-\mathrm{C}(3) & 2.004(6) & 2.035(7) \\ \mathrm{Fe}(1)-\mathrm{C}(4) & 2.096(5) & 2.080(7) \\ \mathrm{Fe}(1)-\mathrm{C}(5) & 1.819(6) & 1.839(7) \\ \mathrm{Fe}(1)-\mathrm{C}(1) & 1.996(6) & 1.944(8) \\ \mathrm{Fe}(2)-\mathrm{C}(1) & 1.874(6) & 1.894(8) \\ \mathrm{C}(1)-\mathrm{O}(1) & 1.167(7) & 1.181(9) \\ \mathrm{Fe}(2)-\mathrm{C}(3) & 1.978(5) & 1.955(7) \\ \mathrm{C}(3)-\mathrm{C}(4) & 1.381(8) & 1.39(1) \\ \mathrm{C}(4)-\mathrm{C}(5) & 1.434(7) & 1.43(1) \\ \mathrm{C}(5)-\mathrm{N} & 1.324(7) & 1.314(8) \\ \mathrm{C}(6)-\mathrm{N} & 1.488(7) & 1.47889) \\ \mathrm{C}(9)-\mathrm{N} & 1.448(8) & 1.454(8) \\ \mathrm{C}(3)-\mathrm{C}(15) & 1.511(8) & 1.54(1) \\ \mathrm{C}(4)-\mathrm{C}(16) & 1.523(7) & 1.52(1) \\ \mathrm{Fe}(2)-\mathrm{C}(2) & 1.741(8) & 1.750(9) \\ \mathrm{C}(2)-\mathrm{O}(2) & 1.150(8) & 1.150(9) \\ \mathrm{Fe}(1)-\mathrm{C}(\mathrm{Cp})(\mathrm{av}) & 2.093 & 2.090 \\ \mathrm{Fe}(2)-\mathrm{C}(\mathrm{Cp})(\mathrm{av}) & 2.119 & 2.109 \\ & & \\ \mathrm{C}(9)-\mathrm{N}-\mathrm{C}(5) & 120.2(5) & 121.9(6) \\ \mathrm{C}(5)-\mathrm{C}(4)-\mathrm{C}(3) & 114.0(5) & 115.5(6) \\ \mathrm{N}-\mathrm{C}(5)-\mathrm{C}(4) & 129.6(5) & 131.3(7) \\ \mathrm{Fe}(2)-\mathrm{C}(3)-\mathrm{C}(4) & 119.484) & 121.8(5) \\ \mathrm{Fe}(1)-\mathrm{C}(5)-\mathrm{C}(4) & 79.3(3) & 77.9(4) \\ \mathrm{C}(5)-\mathrm{N}-\mathrm{C}(6) & 123.4(5) & 121.9(6) \\ \mathrm{C}(6)-\mathrm{N}-\mathrm{C}(9) & 116.3(5) & 116.2(5)\end{array}$


Table 3 Crystal data and experimental details for $\mathbf{2}$, cis-8 and trans-8..

\begin{tabular}{|c|c|c|c|}
\hline Compound & 2 & trans $-\mathbf{8}$ & $c i s-8$ \\
\hline Empirical formula & $\mathrm{C}_{27} \mathrm{H}_{26} \mathrm{~F}_{3} \mathrm{Fe}_{2} \mathrm{NO}_{7} \mathrm{~S}$ & $\mathrm{C}_{27} \mathrm{H}_{28} \mathrm{~F}_{3} \mathrm{Fe}_{2} \mathrm{NO}_{5} \mathrm{~S}$ & $\mathrm{C}_{27} \mathrm{H}_{28} \mathrm{~F}_{3} \mathrm{Fe}_{2} \mathrm{NO}_{5} \mathrm{~S}$ \\
\hline$M_{\mathrm{r}}$ & 677.25 & 647.26 & 647.26 \\
\hline $\mathrm{T} / \mathrm{K}$ & $293(2)$ & $298(2)$ & $298(2)$ \\
\hline$\lambda / \AA$ & 0.71073 & 0.71073 & 0.71073 \\
\hline Crystal system & triclinic & monoclinic & triclinic \\
\hline Space group & $P \bar{l}$ & $P{ }_{l} / c$ & $P \bar{l}$ \\
\hline$a / \AA ̊$ & $10.384(1)$ & $9.0478(4)$ & $8.414(1)$ \\
\hline$b / \AA$ & $11.077(1)$ & $15.4678(7)$ & $12.312(2)$ \\
\hline$c / \AA$ & $12.564(1)$ & $19.4960(9)$ & $14.510(2)$ \\
\hline$\alpha /^{\circ}$ & $83.353(3)$ & 90 & $64.895(3)$ \\
\hline$\beta /^{\circ}$ & $85.939(3)$ & $92.029(2)$ & $82.814(4)$ \\
\hline$\gamma /{ }^{\circ}$ & $77.068(3)$ & 90 & $85.130(4)$ \\
\hline$V / \AA^{3}$ & 1397.6(3) & $2726.7(2)$ & $3735.4(1)$ \\
\hline Z & 2 & 4 & 2 \\
\hline $\mathrm{D}_{\mathrm{c}} / \mathrm{Mg} \mathrm{m}^{-3}$ & 1.609 & 1.577 & 1.593 \\
\hline$\mu\left(\mathrm{Mo}-\mathrm{K}_{\alpha}\right) / \mathrm{mm}^{-1}$ & 1.179 & 1.199 & 1.212 \\
\hline $\mathrm{F}(000)$ & 692 & 1328 & 664 \\
\hline Crystal size/mm & $0.27 \times 0.13 \times 0.10$ & $0.30 \times 0.27 \times 0.20$ & $0.30 \times 0.24 \times 0.20$ \\
\hline$\theta$ limits $/{ }^{\circ}$ & $2.53-23.99$ & $2.61-24.99$ & $1.56-23.27$ \\
\hline Reflections collected & $8336( \pm \mathrm{h}, \pm \mathrm{k}, \pm \mathrm{l})$ & $24727( \pm \mathrm{h}, \pm \mathrm{k}, \pm \mathrm{l})$ & $9993( \pm \mathrm{h}, \pm \mathrm{k}, \pm \mathrm{l})$ \\
\hline $\begin{array}{l}\text { Unique observed reflections } \\
{[\mathrm{I}>2 \sigma(\mathrm{I})]}\end{array}$ & $4302\left[\mathrm{R}_{\mathrm{int}}=0.074\right]$ & $4796\left[\mathrm{R}_{\mathrm{int}}=0.090\right]$ & $3859\left[\mathrm{R}_{\mathrm{int}}=0.072\right]$ \\
\hline Goodness-of-fit-on $\mathrm{F}^{2}$ & 1.069 & 1.020 & 0.940 \\
\hline Final $\mathrm{R}_{1} \mathrm{a}, \mathrm{wR}_{2}\left(\mathrm{~F}^{2}\right)^{\mathrm{b}}[\mathrm{I}>2 \sigma(\mathrm{I})]$ & $0.0647,0.1394$ & $0.0652,0.1694$ & $0.0611,0.1512$ \\
\hline Largest diff. peak and hole/e. $\AA^{-3}$ & 0.723 and -0.612 & 0.532 and -0.694 & 0.618 and -0.580 \\
\hline${ }^{\mathrm{a}} \mathrm{R}_{1}=\Sigma|| \mathrm{Fo}|-| \mathrm{Fc}|/ \Sigma| \mathrm{Fo} \mid$ & & & \\
\hline
\end{tabular}




\section{Stereochemistry of the insertion of disubstituted alkynes into the metal aminocarbyne bond in diiron complexes.}

Vincenzo G. Albano, ${ }^{++}$Luigi Busetto, ${ }^{+}$Fabio Marchetti, ${ }^{+}$Magda Monari, ${ }^{++}$Stefano Zacchini ${ }^{+}$ and Valerio Zanotti ${ }^{+*}$.

${ }^{+}$Dipartimento di Chimica Fisica ed Inorganica, Università di Bologna, Viale Risorgimento 4, I-40136 Bologna, Italy

${ }^{++}$Dipartimento di Chimica “G. Ciamician”, Università di Bologna, Via Selmi 2, I-40126 Bologna, Italy

Alkynes ( $\mathrm{R}$ ' $\mathrm{C} \equiv \mathrm{CR}$ ') insert into the $\mu$-carbon -metal bond of diiron complexes affording $\mu-\sigma: \eta^{3}$ vinyliminium species. Several isomers have been found arising from: i) the iminium moiety configuration $(E, Z)$, ii) mutual Cp position (cis-trans isomers), iii) headhead or head -tail insertion mode of $\mathrm{R}^{\prime} \mathrm{C} \equiv \mathrm{CR}$ '. . These isomeric forms have been investigated by NMRand X-ray diffraction.

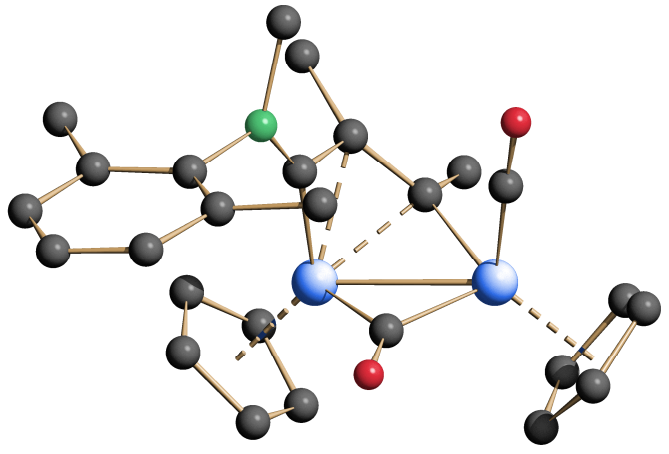

cis

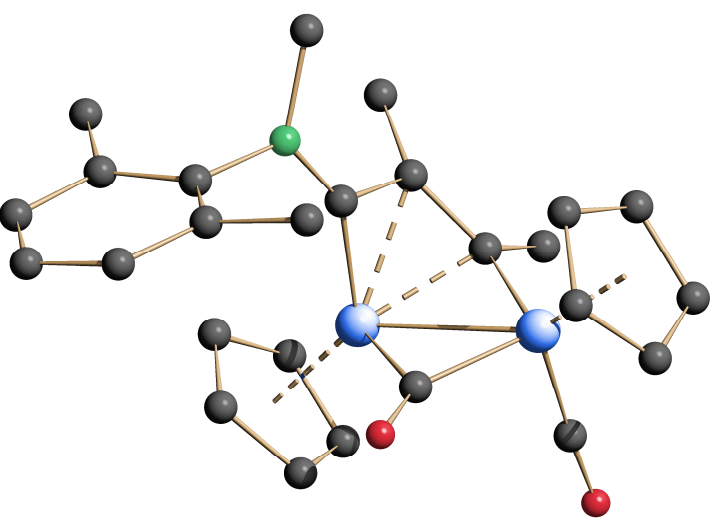

trans 